\title{
The Structure and Replication of Coronaviruses
}

\author{
ST. SidDelL*, H. WegE*, AND V. TeR MeULeN*
}

1 Introduction. . . . . . . . . . . . . . . . . . . . . . 131

2 Structure . . . . . . . . . . . . . . . . . . . . . . . . 134

2.1 Nucleocapsid . . . . . . . . . . . . . . . . . . . . . . . 136

2.11 RNA . . . . . . . . . . . . . . . . . . . . 136

2.1.2 Capsid Protein (Class II) . . . . . . . . . . . . . . . . . . . . 137

2.2 Envelope . . . . . . . . . . . . . . . . . . . . . . . . . 140

2.2 .1 Envelope Proteins. . . . . . . . . . . . . . . . . . . . . . 140

2.2.1.1 Matrix Protein (Class III) . . . . . . . . . . . . . . . . . . . 140

2.2.1.2 Peplomer Protein (Class I) . . . . . . . . . . . . . . . . . . . 141

2.2 .2 Lipids . . . . . . . . . . . . . . . . . . . . . . . . . . 143

3 Replication . . . . . . . . . . . . . . . . . . . . . 143

3.1 Growth . . . . . . . . . . . . . . . . . . . . . . . . 143

3.2 Early Events. . . . . . . . . . . . . . . . . . . . . . . . 144

3.3 Coronavirus-Directed RNA Synthesis . . . . . . . . . . . . . . . . 144

3.4 Coronavirus-Directed Protein Synthesis . . . . . . . . . . . . . . 146

3.4 .1 In Vivo . . . . . . . . . . . . . . . . . . . . . . . . . 146

3.4 .2 In Vitro . . . . . . . . . . . . . . . . . . . . . . . . . 150

3.4.3 Replication Strategy . . . . . . . . . . . . . . . . . . . . . 151

3.5 Virion Assembly . . . . . . . . . . . . . . . . . . . . . . 154

4 Persistent Infection . . . . . . . . . . . . . . . . . . . . . 154

5 Conclusions . . . . . . . . . . . . . . . . . . . . . . . . . 154

References. . . . . . . . . . . . . . . . . 157

\section{Introduction}

Coronaviruses were recognized as a group in 1968 primarily on the basis of their characteristic morphology as seen in the electron microscope (Tyrrell et al. 1968). Since that time our knowledge of the structure and replication of these viruses has increased steadily and has been periodically reviewed (McIntosh 1974; Tyrrell et al. 1978; Robb and Bond 1979a). The basis for this review, which concentrates on the molecular biology of coronaviruses, is principally the new data which has become available in the last 2 years. The pathogenicity of these viruses, which are associated with many diseases of clinical importance in animals and humans, is the subject of the accompanying article.

Coronaviruses infect a wide variety of animal species ranging from fowl to humans. The group comprises 11 recognized viruses, and five more that are tentatively included

\footnotetext{
* Institute of Virology and Immunobiology, Versbacher Straße 7, D-8700 Wuerzburg, Federal Republic of Germany
} 
St. Siddell et al.
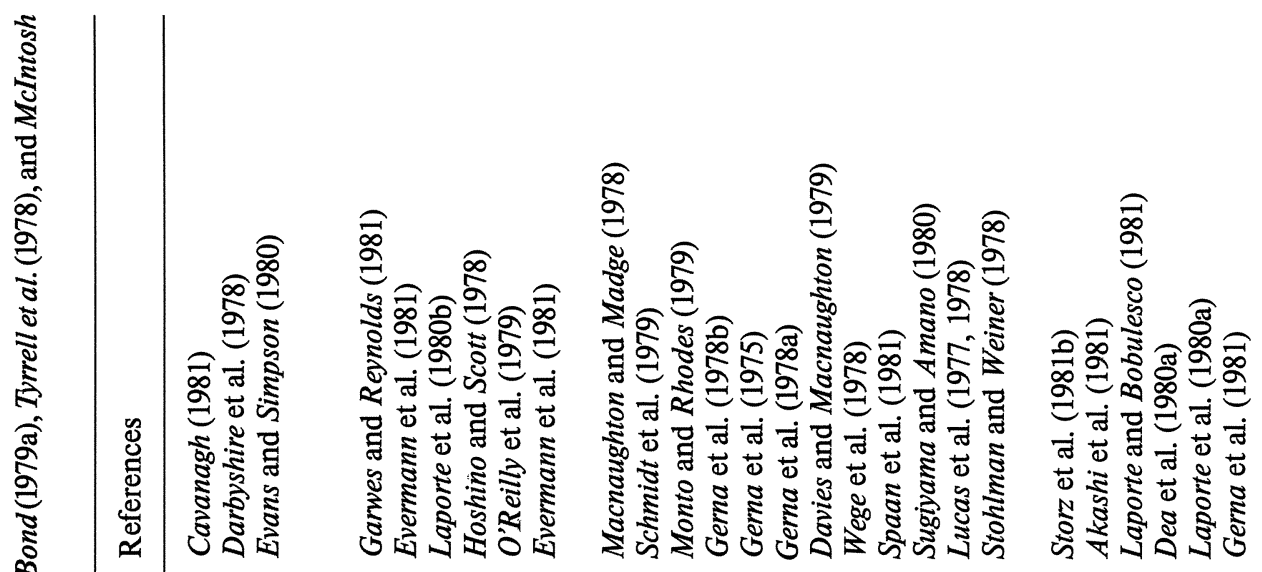

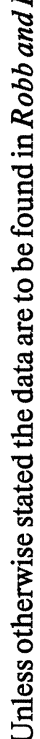

龺

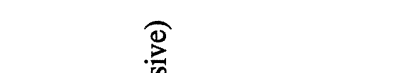

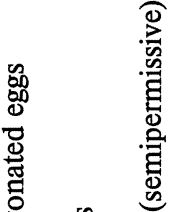

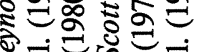

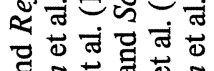

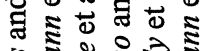

ป⿱艹

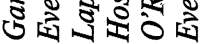

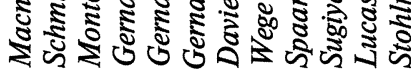

क्य.

莺

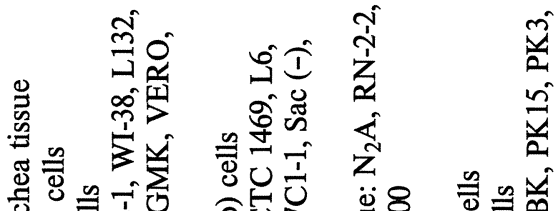

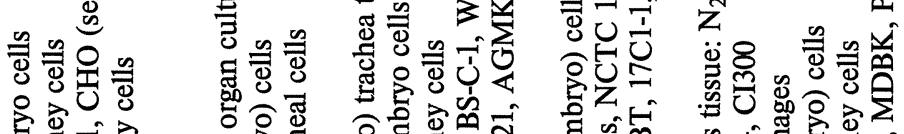

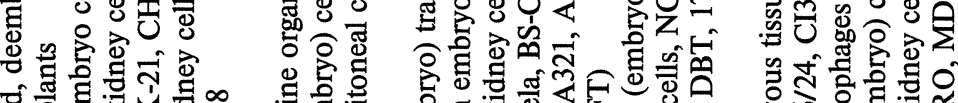

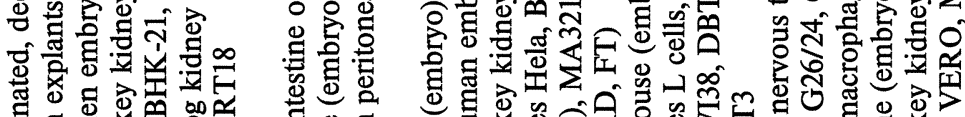

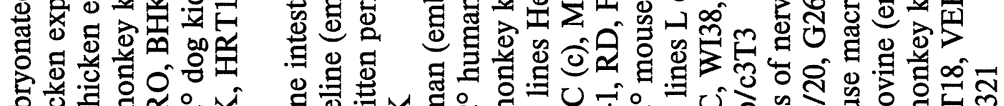

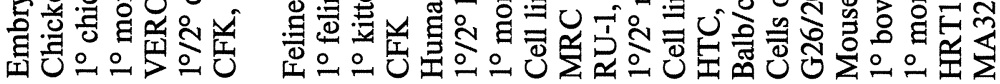

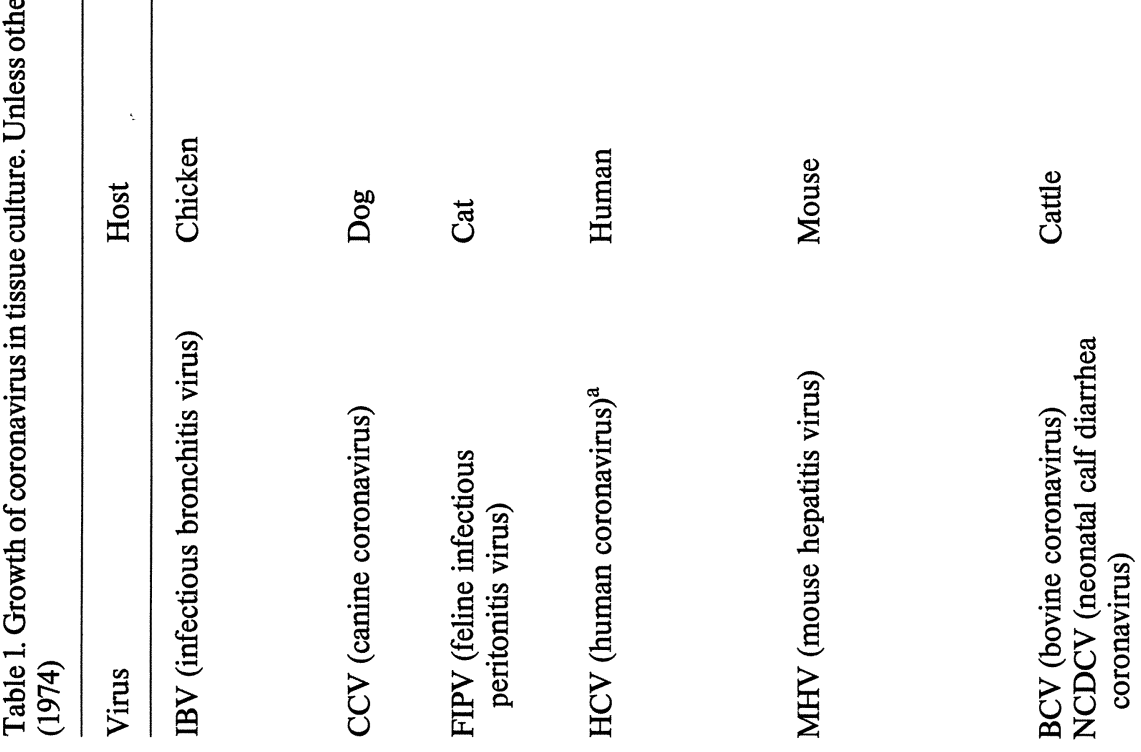



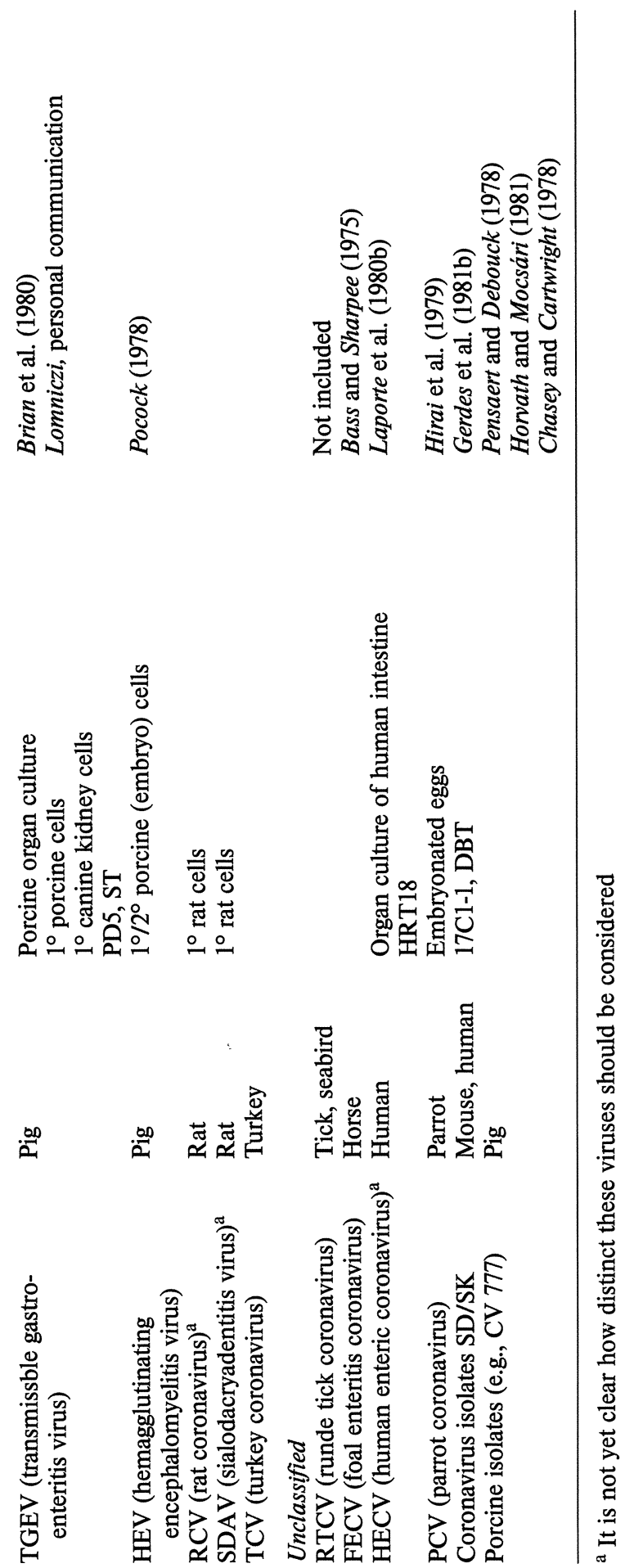
(Table 1). Some members, notably infectious bronchitis virus (IBV) and mouse hepatitis virus (MHV), can be distinguished into several serotypes and others, e.g., human coronavirus (HCV) and human enteric coronavirus (HECV), are presently considered as distinct, although they may be closely related. In general, the inter- and intraspecies serological relationships of coronaviruses remain poorly understood (Tyrrell et al. 1978, $R o b b$ and Bond 1979a), although recent studies indicate that it may soon be possible to define one avian and two mammalian antigenic groups (Pedersen etal. 1978, Macnaughton 1981).

Natural or experimental infections with coronaviruses in vivo are generally restricted to the normal host species. In vitro, coronaviruses also grow most readily in cells from their natural host, although adaptation is possible (Table 1). The ability of different viruses to grow in the available tissue cultures varies greatly and, therefore, two viruses which grow relatively well in vitro, namely IBV and MHV, have been the most intensively studied. Of necessity, we have to rely heavily on these two viruses to illustrate the major features of coronavirus structure and replication. It is clearly an assumption that their features are universal, and data on other coronaviruses are presented when available.

\section{Structure}

Purified virions for morphological, chemical, and physical study can be obtained for most coronaviruses without much difficulty. For example, IBV grown in embryonated eggs or chicken embryo kidney cells yields allantoic fluid or tissue culture medium containing at least $10^{8} \mathrm{EID}_{50} / \mathrm{ml}$ or $10^{8} \mathrm{pfu} / \mathrm{ml}$ virus, respectively (Lanser and Howard $1980 \mathrm{a}$, Stern and Kennedy 1980a). Similarly MHV-A59 grown in 17 Cl-1 cells (a spontaneously transformed derivative of BALB/c 3T3 cells) or Sac(-) cells (a Moloney sarcoma virus transformed cell line) also yields tissue culture medium containing about $10^{8} \mathrm{pfu} / \mathrm{ml}$ virus (Sturman et al. 1980, Spaan et al. 1981). Comparable titers are obtainable with HCV-229E (Hierholzer 1976, Macnaughton et al. 1980), TGEV (Brian et al. 1980), and MHV-JHM (Wege et al. 1979). Viruses such as HEV, CCV, FIPV, MHV-S, MHV-DVIM, and BCV generally produce somewhat lower titers (Pocock and Garwes 1977, Taguchi et al. 1978, Guy and Brian 1979, Garwes and Reynolds 1980, Sugiyama and Amano 1980, Storz et al. 1981a, Everman et al. 1981).

A considerable proportion of the virions synthesized in infected cells is spontaneously released into the surrounding medium or can be released by freezing and thawing, and may therefore be readily purified by standard procedures. Purification involving virion concentration by centrifugation, ammonium sulphate, or polyethylene glycol precipitation followed by rate zonal and isopycnic centrifugation on sucrose, tartrate, or metrizamide density gradients is commonly employed (see ter Meulen et al. (eds) Biochemistry and Biology of Corona viruses 1981 for further references, Hirano et al. 1978; Guy and Brian 1979, Lanser and Howard 1980a, Sugiyama and Amano 1980, Collins and Alexander 1980a, Cavanagh 1981, Spaan et al. 1981). Less commonly, coronavirions have been purified by centrifugation on density gradients of Renograffin or Urografin (Callebaut and Pensaert 1980, Stern et al. 1981), batch chromatography on hydroxylapatite (Hierholzer et al. 1972, Callebaut and Pensaert 1980), and by adsorption to an elution from erythrocytes (Hierholzer et al. 1972). 


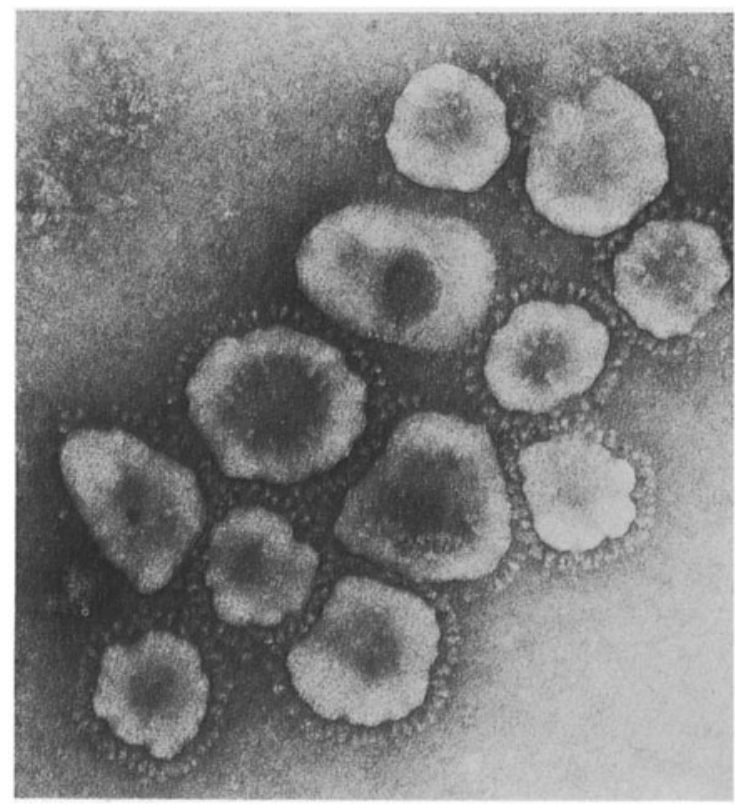

Fig. 1. Coronavirus morphology. The photomicrograph shows a negatively stained preparation of IBV. Magnification $\times 113000$. (Courtesy of J. Almeida)

Coronavirions have a density in sucrose of $1.18 \mathrm{~g} / \mathrm{ml}$ (Robb and Bond, 1979a). Empty particles which have a density of $1.13 \mathrm{~g} / \mathrm{ml}$ and lack ribonucleoprotein (RNP) have been described for IBV (Macnaughton and Davies 1980), but no other coronavirus. The virions are comprised of RNA, protein, carbohydrate (as glycoprotein), and lipids (Tyrrell et al. 1978, Robb and Bond 1979a). Precise data on the chemical composition of coronavirions are not available. The thermolability of coronaviruses appears to resemble that of other enveloped RNA viruses (Laude, 1981).

The morphology of coronavirions has often been described (McIntosh1974, Bingham and Almeida 1977, see Pensaert and Callebaut 1978 for references), usually as pleomorphic, although generally spherical particles 60-220 nm in diameter, with coronas of widely spaced club-shaped surface projections about $20 \mathrm{~nm}$ in length. The virus envelope consists of a distinct pair of electron-dense shells and, in negatively stained preparations of IBV, an inner tongue-shaped membrane is visible (Bingham and Almeida 1977) (Fig. 1). Internal components are not visualized in negatively stained preparations of intact virions (Tyrrell et al. 1978), but may be visible in thin sections (Apostolov et al. 1970).

In agreement with earlier studies (Greig et al. 1971, Stair et al. 1972), it is clear that there are morphological differences in the surface projections of different coronaviruses (Davies and Macnaughton 1979, Caul and Egglestone 1977). It has also been reported that two different forms of surface projections can be discerned on the surface of HEV and MHV-DIVIM virions (Greig et al. 1971, Sugiyama and Amano 1981). Whether these differences in peplomer morphology reflect different configurations of a basic unit or fundamentally different surface projections is not clear (Macnaughton et al. 1977, Macnaughton 1981).

Coronavirions may occasionally disrupt spontaneously or can be disrupted by treatment with detergent, normally Nonidet $\mathrm{P} 40$ or Triton X-100. In both cases, RNP has been 
seen as a long thin stand of 1-2 nm diameter (Davies et al. 1981) or as a helical RNP condensed into coiled structures a varying diameter (normally 10-20 nm). The helical complex appears to be comprised of globular subunits surrounding a hollow core (Kennedy and Johnson-Lussenburg1975/1976, Macnaughton et al. 1978, Caul et al. 1979). Presumably the different forms of complex represent different states of RNP relaxation. Coronaviruses are the first viruses demonstrated to have a positive-stranded genomic RNA (see Sect. 2.1.1) in the form of a helial RNP.

Treatment of coronavirions with strong detergents, such as sodium dodecyl sulphate (SDS) causes total disintegration of the particle allowing study of the virion proteins and RNA. Alternatively, virions can be disrupted by milder detergents (NP40, Triton X-100) and subviral components of different densities can be separated before analysis (Garwes et al. 1976; Pocock and Garwes 1977, Wege et al. 1979, Sturman et al. 1980, Lanser and Howard 1980b, Davies et al. 1981).

\subsection{Nucleocapsid}

After disruption with detergent, nucleocapsid structures may be isolated into density gradients at a higher density than the intact virions. In sucrose, coronavirion nucleocapsids band at approximately 1.27-1.28 g/ml (Wege et al. 1979, Sturman et al. 1980).

\subsubsection{RNA}

The coronavirus genome is a continuous single-stranded molecule of RNA. The size of the molecule has been estimated for a number of viruses by several methods and is about $6 \times 10^{6}$, which would correspond to about 18000 nucleotides (Table 2).

Table 2. Coronavirus genomic RNA. Sizes determined by sedimentation in sucrose density gradients or some earlier reports (Robb and Bond 1979a for review) are not included in this table. Methods are as follows: Electrophoresis after denaturation by methylmercury, glyoxal, or formaldehyde (A); nondenaturing electrophoresis (B); electron microscopic measurement (C)

\begin{tabular}{lllll}
\hline Virus & : & Size $\left(\times 10^{-6}\right)$ & Method & References \\
\hline IBV & Beaudette & 6.9 & A & Stern and Kennedy $(1980 \mathrm{a})$ \\
& Beaudette & 5.8 & B & Macnaughton $(1978)$ \\
& Beaudette & 5.8 & B & Davies et al. (1981) \\
& Beaudette & $6.1-6.6$ & C & Macnaughton and Davies (1980) \\
MHV & A59/JHM & 5.4 & A & Lai and Stohlman $(1978)$ \\
& A59 & 5.6 & B & Spaan et al. (1981) \\
& JHM & 6.7 & A & Wege et al. (1981b) \\
& JHM & $5.4-6.5$ & B & Wege et al. $(1978)$ \\
& A59/JHM & 6.1 & A & Leibowitz et al. (1981) \\
& A59 & 6.0 & A & Weiss and Leibowitz (1981) \\
HCV & 3 & 5.8 & B & Macnaughton $(1978)$ \\
& $229 \mathrm{E}$ & 5.8 & A & Macnaughton and Madge (1978) \\
& OC43 & 6.5 & B & Hierholzer et al. (1981) \\
TGEV & Purdue & 6.1 & B & Macnaughton and Madge (1978) \\
BCV & Mebus & 3.8 & A & Brian et al. (1980) \\
\end{tabular}


$\mathrm{T}_{1}$ oligonucleotide mapping indicates that there is no extensive sequence reiteration in the coronavirus genome (Lomniczi and Kennedy 1977; Leibowitz et al. 1981, Lai and Stohlman 1981a, 1981b, Lai et al. 1981, Stohlman et al. to be published). The genomic RNA is polyadenylated at or near the $3^{\prime}$ end of the RNA and the tract has been calculated to be 70-90 adenylate residues long (Yogo et al.1977, Macnaughton and Madge 1978). Recently, it has been demonstrated for MHV-JHM that the genomic RNA which binds to poly U-Sepharose or oligo-dT-cellulose and that which does not bind have essentially identical $\mathrm{T}_{1}$ oligonucleotide fingerprints, except for a number of spots which differ in their molar ratios (Lai and Stohlman 1981a). These spots correspond to oligonucleotides positioned at the termini of the RNA (Stohlman et al. to be published) and indicate that the poly A(-) RNA reported by many workers (Lomniczi 1977, Schochetman et al. 1977, Yogo et al. 1977, Lai and Stohlman 1978, Wege et al. 1978, Macnaughton and Madge 1978, Tannock and Hierholzer 1978, Guy and Brian 1979, Brian et al.1980) has probably been derived from the poly $\mathrm{A}(+)$ RNA by degradation.

This evidence as well as the infectivity of the coronavirus genomic RNA (Lomniczi 1977, Schochetman et al. 1977, Wege et al. 1978, Brian et al. 1980) and the partial identity of $\mathrm{T}_{1}$ oligonucleotide fingerprints of coronavirus genomic and messenger RNA (see Sect. 3.3) confirms the positive polarity of the virion nucleic acid. The genomic RNA, which can presumably function as a mRNA(see Sect. 5), is also capped (Lai and Stohlman 1981b, Lai et al. 1981) although the cap structure has not yet been determined.

The genomic RNA of a number of MHV serotypes and variants have been compared by molecular hybridization (Weiss and Leibowitz 1981) and in more detail by $\mathrm{T}_{1}$ oligonucleotide fingerprinting (Lai and Stohlman 1981a, 1981b, Stohlman et al. to be published; Wege et al. 1981a). These studies indicate that MHV-A59, and MHV-3 are closely related, while MHV-JHM, MHV-1, MHV-2, and MHV-S have diverged extensively in their genetic sequence. In contrast, the genomic RNA of two plaque morphology variants of MHV-JHM has changed very little. In a similar study the genomic RNA of 13 IBV isolates was analyzed and 11 quite distinct oligonucleotide fingerprints were demonstrated not only between IBV serotypes, but also between variants within a serotype (Clewley et al. 1981). The possible implications of these findings on the serology, biological properties, and pathogenicity of these viruses is considered in the accompanying article.

\subsubsection{Capsid Protein (Class II)}

In addition to RNA, the nucleocapsid of coronaviruses contains a nonglycosylated protein of about 50 000-60000 mol. wt. (Table 3). This protein is relatively rich in arginine and glutamic acid residues (Sturman 1977) and is phosphorylated (Stohlman and Lai 1979, Siddell et al. 1981a, Rottier et al. 1981a, Stern et al 1981, Lomniczi and Morser 1981). Phosphorylation is seen specifically at serine residues in the MHV protein (Stohlman and Lai 1979, Siddell et al. 1981a). Siddell et al. (1981a) demonstrated that purified MHV-JHM virions contain a protein kinase activity which specifically phosphorylates pp60 in vitro. The enzyme has the characteristics of a cyclic AMP-independent protein kinase. It is not yet known whether the enzyme is viral coded, or a sequestered host cell enzyme, or whether it is responsible for the phosphorylation of nucleocapsid protein incorporated into virions. The function of nucleocapsid protein phosphorylation is also unclear, although a role in the interaction between nucleocapsid RNP and the M (matrix) protein of the envelope (see Sect. 2.2.1.1) during virus assembly has been considered (Siddell et al. 
St. Siddell et al.

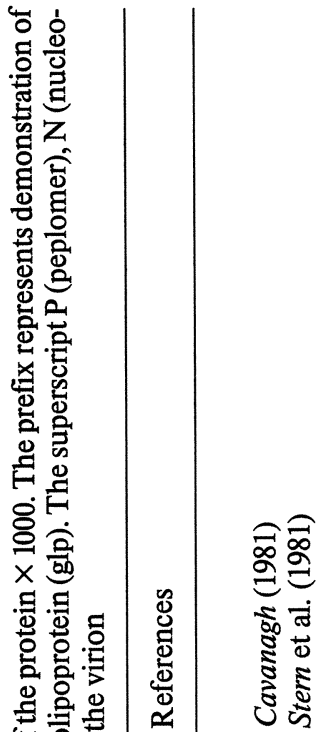

ิํㅇำ

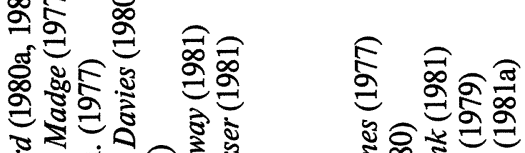

ஓे

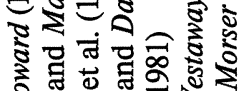

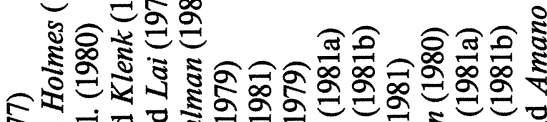

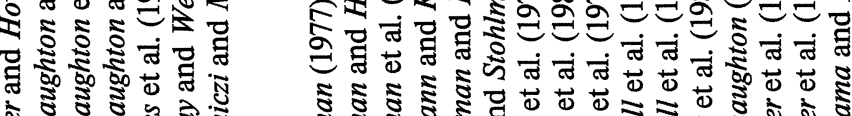
离范

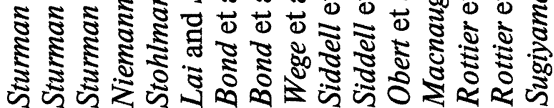
8 댕.

$\sum_{\text {N }} \pm$ किल कूल कू

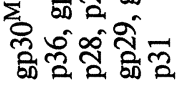

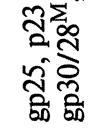

हूँ 西

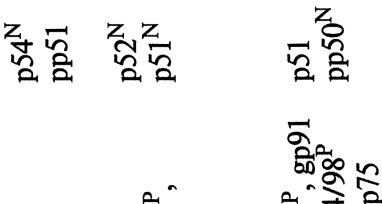

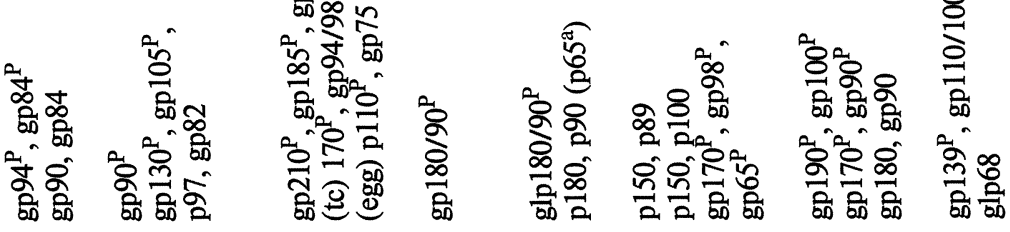

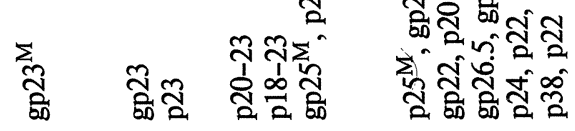




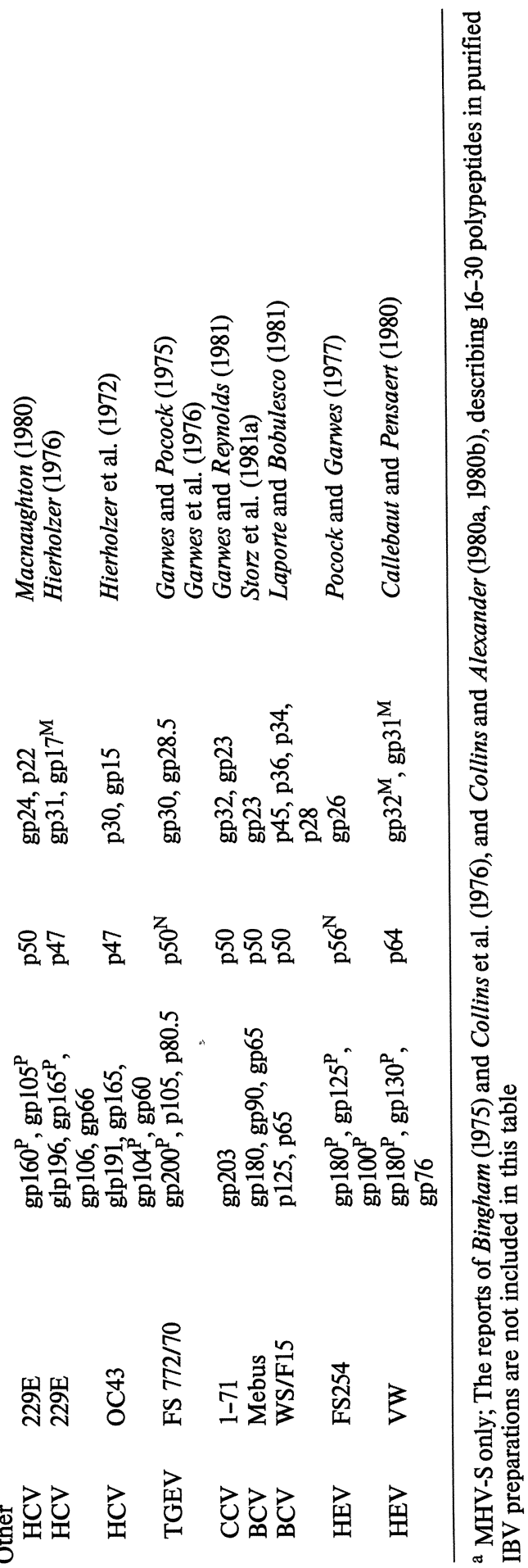


1981a). Monospecific polyvalent antisera directed against MHV nucleocapsid protein can be prepared by conventional procedures (Sturman et al. 1980, Siddell et al. 1980).

\subsection{Envelope}

The virion contains, in addition to the nucleocapsid, a lipid envelope and its integral and peripheral proteins. These components can be isolated by fractionation after mild disruption, taking advantage of specific protein-protein or protein-RNA interactions, or the components can be analyzed after complete solubilization of the virion (Garwes et al. 1976, Wege et al. 1979, Callebaut and Pensaert 1980, Lanserand Howard 1980a, Collins and Alexander 1980b, Sturman et al. 1980, Sturman 1981, Cavanagh 1981).

\subsubsection{Envelope Proteins}

\subsubsection{Matrix Protein (Class III)}

All coronavirions have a major glycoprotein of 20000-30 000 mol. wt. In some reports between one and four additional polypeptides of similar size (which may or may not be glycosylated), have also been described (Table 3 ). The available evidence, which is limited to IBV and MHV, suggests that most of these additional polypeptides are closely related in their primary structure to the major glycoprotein. This conclusion is supported by tryptic peptide mapping of IBV virion proteins (Stern et al.1981), radioisotope labelling experiments in infected cells (see Sect. 3.4.1), and in vitro translation studies (see Sect. 3.4.2). Notable exceptions are the $14000 \mathrm{~mol}$. wt. polypeptide described for IBV by Stern et al. (1981), which appears unrelated to the other low molecular weight species of IBV virions and the minor 14500 mol. wt. polypeptide described for MHV-A59 virions by Rottier et al. (1981b).

A number of experiments indicate the topography of the low molecular weight glycoprotein in the virion. Firstly, exposure of intact virus to proteases (pronase, bromelain) reduces the size of the protein by about 10\%-20\% (Sturman 1977, Wege et al. 1979, Cavanagh 1981, Callebaut and Pensaert 1980), with a concomitant loss of carbohydrate (Sturman 1977). Thus, a small glycosylated portion of the molecule is peripheral to the lipid membrane. It is presumably this portion of the molecule that binds $\mathrm{I}^{125}$-labelled concavalin A (Lanser and Howard 1980a). Secondly, the behavior of this protein in SDSpolyacrylamide gels after reduction suggests a second, strongly hydrophobic domain, rich in disulphide bridges, which is thought to correspond to a portion of the molecule integral to the lipid membrane (Sturman 1981). Thirdly, virions can be disrupted by NP40 at $4{ }^{\circ} \mathrm{C}$ and nucleocapsids and envelope proteins separated on density gradients. When the low molecular weight glycoprotein and nucleocapsids are remixed at $37^{\circ} \mathrm{C}$, a stable complex is formed (Sturman et al. 1980, Sturman 1981), specifically between the protein and virion RNA. This finding suggests a third domain on the protein, which is internal to the lipid membrane and is responsible for the interaction with viral nucleocapsids. Thus, the low molecular weight coronavirus glycoprotein seems to possess the properties expected of an $\mathrm{M}$ protein although, in contrast to the $\mathrm{M}$ protein of other enveloped RNA viruses, it is glycosylated. Its function as a matrix protein is also supported by intracellular 
studies (see Sect. 3.4.1). Antiserum directed against purified MHV-A59 M protein has been prepared by conventional procedures (Sturman et al. 1980).

The oligosaccharide component of MHV-A59 M protein has been studied in some detail and has been found to be unlike any previously described for a viral glycoprotein. The glycosylated molecule has an apparent mol. wt. of 23000 and is rich in methionine residues (Sturman 1977). The oligosaccharide side chain can be metabolically labelled by glucosamine and galactose, but not by fucose or mannose (Sturman 1977, Niemann and Klenk 1981). A similar labelling pattern has also been observed for the $\mathbf{M}$ protein of bovine coronaviruses (BCV) (Storz et al. 1981a). Chemical analysis shows the carbohydrates of the molecule to consist of galactose, $\mathrm{N}$-acetyl glucosamine, $\mathrm{N}$-acetyl galactosamine, and neuraminic acid, a profile typical of an O-glycosidic-linked side chain rather than the $\mathrm{N}$-glycosidic-linked side chains found in viral glycoproteins (Niemann and Klenk 1981).

This important finding is supported by $\beta$-elimination reactions (Niemann and Klenk 1981) and the study of MHV-A59 M protein formation in tunicamycin-treated cells. Tunicamycin, which inhibits the formation of dolichol-linked $\mathrm{N}$-acetyl glucosamine (an early intermediate in the formation of oligosaccharides subsequently $\mathrm{N}$-glycosidically linked to asparagine residues) does not prevent the glycosylation of the M protein (see Sect. 3.4.1). Virions are released from tunicamycin-treated infected cells with apparently normal M protein and nucleocapsid components (Sturman 1981, Holmes et al. 1981, Rottier et al. 1981b). This result emphasizes the importance of the $\mathrm{M}$ protein in the formation of the viral envelope and virion budding. The so-called bald virion particles released from tunicamycin-treated cells are, however, noninfectious and lack the second envelope component, the peplomer protein.

\subsubsection{Peplomer Protein (Class I)}

The third class of coronavirion proteins are glycoproteins of mol. wt. 80 000-200000 (Table 3). For most coronaviruses, one or more usually two major species have been described. However, tryptic peptide fingerprinting of the MHV-A59 polypeptides (Sturman and Holmes 1977) and in vivo and in vitro translation studies (see Sect. 3.4.1, 3.4.2) again suggest that these species are derived from a single primary translation product which is modified by post-translational cleavage.

A number of experiments show that the major high molecular weight glycoproteins form the surface peplomers of the virion. Firstly, the glycoproteins are preferentially removed from the virion by treatment with pronase, bromelain or urea, detergent, or reducing agents, and the resulting particle which has lost its infectivity lacks peplomer structures when visualized in the electron microscope (Hierholzer et al. 1972, Garwes and Pocock1975, Garwes et al. 1976, Pocockand Garwes 1977, Macnaughton et al. 1977, Sturman 1977, Sturman and Holmes 1977, Wege et al. 1979, Callebaut and Pensaert 1980, Sugiyama and Amano 1980, Macnaughton 1980, Waday and Westaway 1981). Secondly, more vigorous treatment of virions with detergents solubilizes the envelope components which can then be separated into density gradients. The lightest fraction, which is comprised of the high molecular weight glycoprotein alone, aggregates when the detergent is removed, and forms structures which appear electron microscopically as rosettes of peplomers (Sturman et al. 1980, Collins and Alexander 1980b). Polyvalent monospecific 
antiserum directed against purified peplomer protein has been prepared using this technique (Sturman et al. 1980).

In MHV-A59 virions the peplomer protein exists as related forms with mol. wit. of $90000-180000$ (see Sect. 3.4.1). The polypeptides are rich in both intramolecular disulphide bonds and free sulphydryl groups, both of which are necessary to maintain the native configuration and biological function of the protein (Pocock and Garwes 1975, Alexander and Collins 1975, Sturman 1981). Both forms of the glycoprotein can be metabolically labelled with glucosamine, galactose, fucose, mannose, and palmitic acid (Niemann and Klenk 1981, Sturman 1981, Rottier et al. 1981b), as can the corresponding proteins of BCV (Storz et al. 1981a), and glycosylation of the MHV protein is inhibited by tunicamycin (see Sect. 3.4.1). This result indicates that, in constrast to the M protein, the oligosaccharide side chain of the peplomer protein is N-glycosidically linked.

Noninfectious virions are produced from MHV-infected tunicamycin-treated cells and are devoid of peplomer protein (Holmes et al. 1981, Sturman 1981, Rottier et al. 1981b). These virions are unable to reabsorb to the plasmalemma and cell fusion is markedly reduced in cells releasing bald particles. This suggests that the peplomer protein plays a crucial role in the reception of virions onto cell surfaces and also in the induction of cell fusion. However, further evidence is needed before the surface functions that have been described for different coronaviruses, namely hemabsorption, hemagglutination, and cell fusion (Kapikian et al. 1972, Bingham et al. 1975; Bridger et al. 1978, Pocock 1978, Walkerand Cleator 1980, Sugiyama and Amano 1980, Callebaut and Pensaert 1980, Storz et al. 1981b, Holmes et al. 1981) are all considered as properties of the peplomer protein alone. Table 3 shows that at least some coronaviruses appear to possess other surface pro-

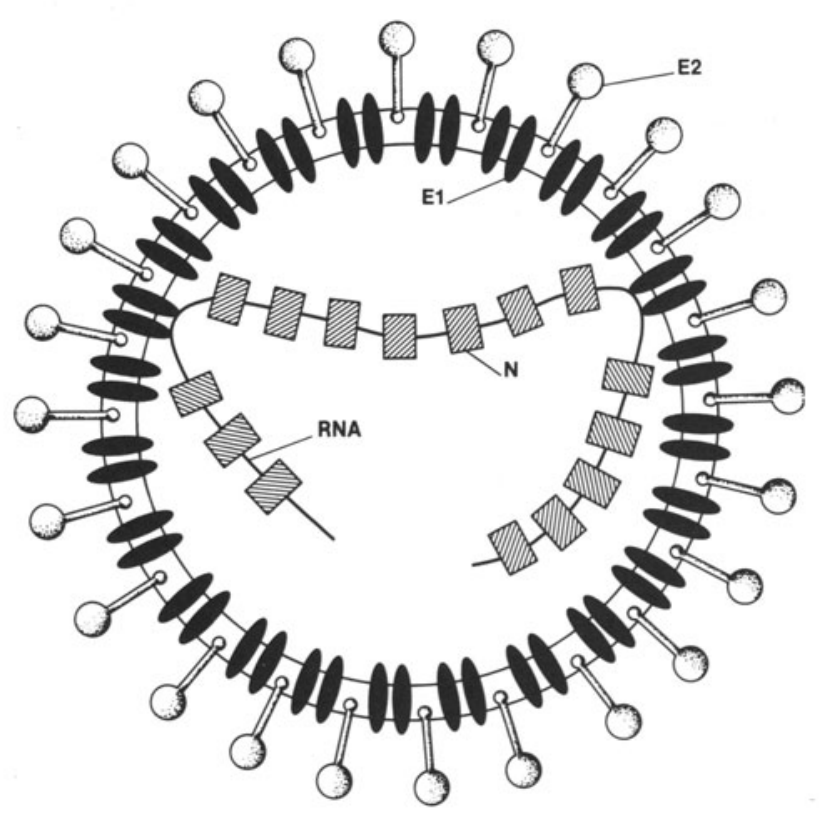

Fig. 2. A schematic model of coronavirus MHV-A59; genomic $(R N A)$, nucleocapsid protein $(N)$, matrix protein (EI), peplomer protein (E2). (Courtesy of $L$. Sturman) 
teins or glycoproteins. These additional proteins do not yet fit into any consistent pattern and are frequently minor components. Nevertheless, their significance remains unclear. There are also preliminary indications that, as in the case of ortho- and paramyxoviruses (Klenk and Rott 1981), proteolytic processing during the morphogenesis of the coronavirion may be involved in activating surface functions (Dea et al. 1980a, Storz et al. 1981b, see also Yoshikura and Tejina 1981).

\subsubsection{Lipids}

The viral envelope of TGEV contains phospholipids, glycolipids, cholesterol, di-and triglycerides, and free fatty acids in proportions approximately corresponding to those in the cell. Cholesteryl and fatty acid esters present in cell membranes are selectively depleted in the virus membrane. When grown in different cell types the viral membrane reflects the lipid content of the host cell in which it was grown, suggesting that the lipids of the virion are derived from the host cell (Pike and Garwes 1977).

To summarize this section, a model describing the possible structure of a coronavirus and its relationship to the RNA and polypeptide components of the virion is given in Fig. 2. The model is consistent with the data available for several coronaviruses, but is based on experiments performed by Sturman et al. (1980) with MHV-A59.

\section{Replication}

\subsection{Growth}

Coronaviruses grow in a wide variety of cells (Table 1). Infection is initiated by one-hit kinetics, after which a lage phase of $2-4 \mathrm{~h}$ is followed by a period of approximately $6 \mathrm{~h}$ during which virus is released into the medium. For MHV and IBV the one-step growth curve at $37^{\circ} \mathrm{C}$ is completed by about $10-12 \mathrm{~h}$ and comparable growth curves have been shown for TGEV, BCV, and HCV-229E (Robb and Bond 1979b, Guy and Brian 1979, Brian et al. 1980, Stern and Kennedy 1980a, Hierholzer et al. 1981, Spaan et al. 1981, Wege et al. 1981c, Lai et al. 1981, Leibowitz et al. 1981). About 50\% of MHV infectivity remains cellbound at the end of the replication cycle. The relationship between the multiplicity of infection and the virus yield is as theoretically expected (Spaan et al. 1981).

Coronavirus infection is often accompanied by cytopathic changes, most frequently cellular vacuolation leading to disintegration or in some cases syncytium formation (Tyrrell et al. 1978). There have been no quantitative studies on host-cell DNA, RNA, or protein synthesis in infected cells. Host-cell protein synthesis in the Sac(-) cell line has been arrested at late times of infection with MHV (Siddell et al. 1981b, Rottier t al. 1981b), but nothing is known about the mechanism of this action.

Like other positive-stranded viruses, the replication of coronaviruses would be expected to occur exclusively in the cytoplasm of infected cells without the involvement of any nuclear function. This conclusion appears to be supported by immunofluorescence and electron microscopic studies (McIntosh 1974, Robb and Bond 1979a) and the ability of $\mathrm{MHV}, \mathrm{IBV}$, and other coronaviruses to grow equally well in the presence or absence of actinomycin-D and inhibitors of DNA metabolism (Malluci 1965, McIntosh 1974; Hirano 
et al. 1978, Dea et al. 1980a, Stern and Kennedy 1980a, Spaan et al. 1981, Wege et al. 1981b, Brayton et al. 1981, Leibowitz et al. 1981). It has also been reported that MHV-A59 and MHV-JHM can replicate in enucleated cells (Wilhelmsen et al. 1981, Brayton et al. 1981).

In contrast to this evidence, however, Evans et al. (1980) report that the growth of IBV is prevented in BHK-21 cells when they are enucleated, UV irradiated, or treated with alpha-amanitin. The virus did, however, grow in an alpha-amanitin-resistant Chinese hamster ovary $(\mathrm{CHO})$ cell line in the presence of the drug. These results cannot be easily reconciled with the majority of the available data but they do show that there must be further experimentation before this question is resolved.

\subsection{Early Events}

Coronaviruses attach to the surface of cells quickly and equally well at both $4{ }^{\circ} \mathrm{C}$ and $37^{\circ} \mathrm{C}$ (Robb and Bond 1979a). Patterson and Macnaughton (1981) have recently shown that, on monolayer cells infected with HCV-229E, virions are initially attached over the whole cell surface but are then rapidly redistributed away from the cell periphery by an energy-requiring process. The reason for this redistribution is not known. Virion nucleocapsids subsequently penetrate the cell and both viropexis and envelope-membrane fusion have been described as mechanisms of penetration (Patterson and Bingham 1976, Doughri et al. 1976). The mechanism by which nucleocapsids are uncoated after entering the cell is unknown.

\subsection{Coronavirus-Directed RNA Synthesis}

Labelling coronavirus infected cells with ${ }^{3} \mathrm{H}$-uridine in the presence of actinomycin-D at any time after the initial lag phase of replication reveals the synthesis of six or seven major cytoplasmic RNA species with molecular weights ranging from $0.6 \times 10^{6}$ to about 6-7 $\times 10^{6}$ (Table 4). All of the RNA species detected are single-stranded and at least a proportion of each binds to poly-U-Sepharose or oligo-dT cellulose. Selection of RNA for polyadenylation does not alter the ratio of the species, and the ratio in which they are syn-

Table 4. Coronaviruses intracellular RNA. Sizes determined by sedimentation in sucrose gradients or some earlier reports (Robb and Bond 1979a for review) are not included in this table

\begin{tabular}{|c|c|c|c|c|c|c|c|c|c|}
\hline Virus & Strain & $\begin{array}{l}1 \\
\text { (Genome } \\
\text { size) }\end{array}$ & 2 & 3 & 4 & 5 & 6 & 7 & References \\
\hline IBV & Beau & 6.9 & - & 2.6 & 1.5 & 1.3 & 0.9 & 0.8 & Stern and Kennedy (1980a) \\
\hline MHV & A59/JHM & 6.1 & 3.4 & 2.6 & 1.2 & 1.1 & 0.8 & 0.6 & Leibowitz et al. (1981) \\
\hline MHV & A59 & 5.6 & 4.0 & 3.0 & 1.4 & 1.2 & 0.9 & 0.6 & Spaan et al. (1981) \\
\hline MHV & A59 & 5.4 & 4.0 & 3.0 & 1.5 & 1.2 & 0.9 & 0.6 & Lai et al. (1981) \\
\hline MHV & JHM & 6.7 & 3.4 & 2.8 & 1.4 & 1.2 & 0.9 & 0.6 & Wege et al. (1981b) \\
\hline MHV & JHM/A59/3 & 6.0 & 3.6 & 3.0 & 1.3 & 1.2 & 0.9 & 0.6 & Weiss and Leibowitz (1981) \\
\hline $\mathrm{HCV}$ & $229 \mathrm{E}$ & 6.0 & 2.8 & 2.1 & 1.3 & 1.0 & 0.8 & 0.6 & Weiss and Leibowitz (1981) \\
\hline TGEV & Purdue & 6.8 & 3.2 & - & 1.4 & - & 0.9 & 0.7 & Dennis and Brian (1981) \\
\hline
\end{tabular}


thesized does not differ markedly at different times during the infection (Stern and Kennedy 1980a, Wege et al. 1981b, Spaan et al. 1981, Dennis and Brian 1981, Leibowitz et al. 1981, Weiss and Leibowitz 1981).

Estimated relative molarities of each species (Stern and Kennedy 1980a, Leibowitz et al. 1981, Jacobs et al. 1981) indicate that the synthesis of RNA 7 and 6 (and, in IBV-and MHV-A59-infected cells, RNA 5 also) is relatively abundant throughout the infection. In MHV-A59-infected cells the majority of the largest RNA (RNA 1) is associated with EDTA-resistant structures, presumably nucleocapsids. The remaining RNA $1(10 \%)$ and all of the other RNAs are associated with polysomes, as are the MHV-JHM RNAs found in infected cells (Robb and Bond 1979b, Spaan et al. 1981, Wege et al. 1981c).

These recent data suggest that the intracellular species described to date are positivestranded and can function as mRNA (see Sect. 3.4.2). The data does not provide any evidence of hybrid RNA molecules evidence or negative-stranded virus-specific RNA. Also, the species described do not seem to be defective viral RNA because their relative proportion does not alter in cells infected with virus that has been propagated by undiluted passage. Moreover, it can be shown that cells producing this spectrum of subgenomic RNA were infected with virions containing only genomic-sized RNA and that the virions produced by these cells contain only genomic-sized RNA (Stern and Kennedy 1980a, Spaan et al. 1981).

The sequence relationship of the intracellular RNAs to each other, and to the coronavirus genomic RNA has been established for IBV and MHV (Stern and Kennedy 1980a, 1980b; Leibowitz et al. 1981, Lai et al. 1981). Clearly, as the sum of the molecular weights of the subgenomic RNA exceeds that of the virion genomic RNA, they must share common sequences if they are related. $\mathrm{T}_{1}$ oligonucleotide mapping shows that the intracellular RNA 1 corresponds to the genomic RNA of virions and that all intracellular subgenomic RNAs form a nested set, the sequence of each RNA being contained within the sequence of all larger RNAs (Stern and Kennedy 1980a, Leibowitz et al. 1981, Lai et al. 1981). Furthermore, by ordering the $T_{1}$ oligonucleotides of the genomic RNA, Stern and Kennedy (1980b) and Lai et al. (1981) showed that the nested set extends inwards from the $3^{\prime}$ terminus of the genome (Fig. 3).

The conclusion that all subgenomic RNAs have identical $3^{\prime}$ sequences is further supported by base composition analysis of the poly A containing $\mathrm{T}_{1}$ oligonucleotides from each RNA ( Lai et al. 1981), and by the hybridization of a cDNA probe specific to the $3^{\prime}$ end of genomic RNA to all subgenomic species (Weiss and Leibowitz 1981). These studies also confirmed that each subgenomic RNA was polyadenylated, with stretches of 100-130 adenylate residues ( Lai et al. 1981). The presence in some RNAs of anomalous oligonucleotides, which do not fit the nested set model, possibly indicates nucleotide modifications (e.g., capping) or minor sequence rearrangements. The importance of these findings to our understanding of the replication strategy employed by coronaviruses is discussed in Sect. 3.4.2.

As stated, no replicative intermediate structures or replicative forms have been demonstrated for coronavirus-infected cells, and the mechanism by which the virus-specific subgenomic RNAs are synthesized and the regulation of their synthesis is not yet known. Van der Zeijst et al. (1981) and Jacobs et al. (1981) have, however, shown that there is a strong correlation between the physical size of genomic- and subgenomic-sized RNAs and the calculated dose of UV irradiation required to block their synthesis. These data suggest that the subgenomic RNAs are synthesized by independent initiation on one 
or more template molecules rather than by the processing of a full-length positive strand synthesized from a template. The data also suggest that a mechanism similar to that shown for vesicular stomatitis virus (VSV) in vitro (Testa et al. 1980) is not used. The data does not, however, discriminate between a full-length negative-strand template or smaller templates and does not exclude short $5^{\prime}$ terminal sequences, which are common to all subgenomic RNAs.

The incorporation of labelled nucleotides into RNA in the presence of actinomycin-D roughly measures the level of RNA polymerase activity in the cell. In MHV-infected cells, virus-specific RNA synthesis is not detectable during the first $2-4 \mathrm{~h}$ after infection. Thereafter, it rises exponentially until 11-12 $\mathrm{h}$ after infection when it remains constant (Spaan et al. 1981, Wege et al. 1981c, Lai et al. 1981, Leibowitz et al. 1981). Towards the end of the replication cycle there is at least a 20 -fold stimulation of ${ }^{3} \mathrm{H}$-uridine incorporation in infected cells as compared to uninfected cells.

Clearly, a virus-specific RNA polymerase is active in infected cells, but there has been only one demonstration of this activity in subcellular fractions. Dennis and Brian (1981) have reported the isolation of an RNA-dependent RNA polymerase activity from TGEVinfected cells which was cytoplasmic and associated with membrane structures. However, as the enzyme was approximately 5000 -fold less active than, for example, the virus-specific RNA polymerase detected in semliki forest virus (SFV)-infected cells (Clewley and Kennedy 1976), this report needs to be confirmed and extended to other coronaviruses. There have been no reported attempts to purify RNA polymerase activity from infected cells and identify its polypeptide components.

\subsection{Coronavirus-Directed Protein Synthesis}

\subsubsection{In Vivo}

The proteins synthesized in cells infected with IBV, MHV, and the multiple sclerosis isolates SK and SD have been labelled with radioactive amino acids and analyzed by polyacrylamide gel electrophoresis (Table 5). In these analyses a number of polypeptides can be recognized, the syntheses of which are either novel or greatly increased above any comparable polypeptide in uninfected cells, or whose synthesis continues if host-cell protein synthesis is arrested. These polypeptides in some cases have been further identified as virus-specific by immunoprecipitation with antiserum from experimentally infected or immunized animals and, to a limited extent, by tryptic peptide fingerprinting. There is also supportive evidence from in vitro translation studies (see Sect. 3.4.2) suggesting that some of these polypeptides are encoded by viral mRNA. There are no precise quantitative data on the synthesis of virus proteins during infection, although their synthesis appears to be coordinated throughout the replication cycle (Siddell et al. 1981b, Rottier et al. 1981b). The relationships between the synthesis of a particular protein and the abundance of its mRNA during the infection have not been investigated.

The most readily detected polypeptide in coronavirus-infected cells is nonglycosylated with mol. wt. 50000-60000 (Table 5). The protein has been specifically immunoprecipitated from IBV-, MHV-, and SD/SK-infected cells by hyperimmune serum (Bond et al. 1979, Siddell et al. 1981b, Van der Zeijst et al. 1981, Rottier et al. 1981b, Gerdes et al. 1981b, Morserand Lomniczi to be published) and, in the case of the MHV-JHM protein, 
Table 5. Coronavirus intracellular proteins. Polypeptides in italics are detected after short ( $30 \mathrm{~min}$ or less) pulse labelling. Polypeptides in parentheses are probably nucleocapsid degradation products (see text)

\begin{tabular}{|c|c|c|c|c|c|c|}
\hline Virus & Strain & Class I & Class II & Class III & Other & References \\
\hline IBV & Beau & $165 K$ & $51 K(42 K)$ & $31 K$ & & Stern et al. (1981) \\
\hline IBV & Beau & $150 K^{a}, 55 K^{a}$ & $50 K^{a}$ & $\begin{array}{l}38 K^{a}, 36 K^{a}, \\
30 K^{a}\end{array}$ & & $\begin{array}{l}\text { Morser and Lom- } \\
\text { niczi (1981) }\end{array}$ \\
\hline IBV & Conn & $150 K^{a}, 55 K^{a}$ & $50 K^{a}$ & $28 K^{a}, 26 K^{a}$ & & $\begin{array}{l}\text { Morser and Lom- } \\
\text { niczi (to be pu- } \\
\text { plished) }\end{array}$ \\
\hline MHV & A59 & $\begin{array}{l}g p 150 K^{a}, 110 K^{a, b} \\
\text { gp90K }\end{array}$ & $\begin{array}{l}54 K^{a} \\
\left(51 K^{a}\right. \\
\left.48 K^{a}\right)\end{array}$ & $\begin{array}{l}\text { gp26.5 } \\
\text { gp25.5K } \\
24 K^{a}, 22 K^{a}\end{array}$ & $14.5 \mathrm{~K}^{\mathrm{a}}$ & $\begin{array}{l}\text { van der Zeijst } \\
\text { et al. (1981) } \\
\text { Rottier et al. } \\
\text { (1981b) }\end{array}$ \\
\hline MHV & A59 & $180 K$ & $50 K$ & $23 \mathrm{~K}, 20 \mathrm{~K}$ & $17 \mathrm{~K}$ & $\begin{array}{l}\text { Holmes et al. } \\
\text { (1981) }\end{array}$ \\
\hline MHV & A59 & $\begin{array}{l}g p 150 K^{a}, 89 \mathrm{~K}^{\mathrm{a}, \mathrm{c}} \\
74 \mathrm{~K}^{\mathrm{a}, \mathrm{c}}\end{array}$ & $\begin{array}{l}60 K^{a} \\
\left(57 K^{a},\right. \\
\left.54 K^{a}\right)\end{array}$ & $23 / 20 K^{a}$ & $\begin{array}{l}39 \mathrm{~K} \\
37 \mathrm{~K} \\
22 \mathrm{~K}^{\mathrm{a}}\end{array}$ & $\begin{array}{l}\text { Bond et al. (1979) } \\
\text { Bond et al. (1981) }\end{array}$ \\
\hline MHV & A59 & $180 \mathrm{~K}^{\mathrm{a}, \mathrm{d}}$ & $50 \mathrm{~K}^{\mathrm{a}, \mathrm{d}, \mathrm{e}}$ & $\begin{array}{l}24 \mathrm{~K}^{\mathrm{a}, \mathrm{d}} \\
23 \mathrm{~K}^{\mathrm{a}, \mathrm{d}} \\
22 \mathrm{~K}^{\mathrm{a}, \mathrm{d}}\end{array}$ & & $\begin{array}{l}\text { Gerdes et al. } \\
\text { (1981a) } \\
\text { Gerdes et al. } \\
\text { (1981b) }\end{array}$ \\
\hline $\mathrm{MHV}^{\mathrm{f}}$ & A59 & gp180K, gp90K & & gp23K & & $\begin{array}{l}\text { Niemann and } \\
\text { Klenk (1981) }\end{array}$ \\
\hline MHV & JHM & $\begin{array}{l}170 \mathrm{~K}^{\mathrm{a}}, 150 \mathrm{~K}^{a} \\
120 \mathrm{~K}^{a, b}, 98 \mathrm{~K}^{\mathrm{a}} \\
65 \mathrm{~K}^{a}\end{array}$ & $\begin{array}{l}p p 60 K^{a} \\
\left(58 K^{a}\right)\end{array}$ & $\begin{array}{l}25 \mathrm{~K}^{\mathrm{a}}, 23 K^{a} \\
23 \mathrm{AK}^{\mathrm{a}, \mathrm{c}}\end{array}$ & $30 K, 14 K$ & $\begin{array}{l}\text { Siddell et al. (1980) } \\
\text { Siddell et al. } \\
\text { (1981a) } \\
\text { Siddell et al. } \\
\text { (1981b) } \\
\text { Siddell et al. } \\
\text { (1981c) }\end{array}$ \\
\hline MHV & JHM & $\begin{array}{l}g p 150 K^{a}, 84 \mathrm{~K}^{\mathrm{a}, \mathrm{c}} \\
70 \mathrm{~K}^{\mathrm{a}, \mathrm{c}}\end{array}$ & $\begin{array}{l}63 K^{a} \\
\left(61 K^{a}\right. \\
\left.56 K^{a}\right)\end{array}$ & $23 / 18 K^{a}$ & $\begin{array}{l}39 \mathrm{~K}, 36 \mathrm{~K} \\
22 \mathrm{~K}^{\mathrm{a}}\end{array}$ & $\begin{array}{l}\text { Bond et al. (1979) } \\
\text { Bond et al. (1981) }\end{array}$ \\
\hline MHV & 3/JHM & $g p 180 K$ & $\begin{array}{l}56 K \\
(50 \mathrm{~K})\end{array}$ & $24 K, 22 K$ & & $\begin{array}{l}\text { Anderson et al. } \\
\text { (1979) }\end{array}$ \\
\hline MS isolates & SD/SK & $180 \mathrm{~K}^{\mathrm{a}}, 90 \mathrm{~K}^{\mathrm{a}}$ & $\begin{array}{l}50 \mathrm{~K}^{\mathrm{a}} \\
\left(42 \mathrm{~K}^{\mathrm{a}}\right)\end{array}$ & $\begin{array}{l}24 \mathrm{~K}^{\mathrm{a}}, 23 \mathrm{~K}^{\mathrm{a}} \\
22 \mathrm{~K}^{\mathrm{a}}\end{array}$ & & $\begin{array}{l}\text { Gerdes et al. } \\
\text { (1981a) } \\
\text { Gerdes et al. } \\
(1981 b)\end{array}$ \\
\hline
\end{tabular}

${ }^{a}$ Immunoprecipitable with homologous antiserum; ${ }^{b}$ Seen only in tunicamycin-treated cells; ${ }^{c}$ Seen only by two-dimensional PAGE; ${ }^{\mathrm{d}}$ Immunoprecipitable with heterologous (anti-SK, anti$\mathrm{SD}$, anti-OC43) serum; ${ }^{\mathrm{e}}$ Immunoprecipitable with heterologous (anti-229E) serum; ${ }^{\mathrm{f}}$ Labelling with ${ }^{3} \mathrm{H}$-glucosamine; $\mathrm{K}$ is used to denote molecular weight $\times 1000$ and also indicate the polypeptide is intracellular 
conclusively identified as the intracellular form of the virion nucleocapsid protein by tryptic peptide fingerprinting (Siddell et al. 1980). The MHV protein is rich in arginine and is phosphorylated specifically at serine residues, as is the virion protein (Anderson et al. 1979, Siddell et al. 1981a, Rottier et al. 1981a) (see Sect. 2.1.2). The number of phosphorylation sites is unknown. Consistent with these findings the intracellular nucleocapsid precursor is basic; migrating rapidly in NEPHGE (Bond et al. 1979; Siddell et al. 1981a, 1981b). The intracellular form of the protein has the same molecular weight in SDS gels as the virion protein (see Tables 3,5 ) and apart from phosphorylation no other modifications have been described for this protein.

The synthesis of the intracellular nucleocapsid precursor has been detected within 3-4 h after infection (Anderson et al. 1979, Stern et al. 1981, Siddell et al. 1981a, Holmes et al. 1981, Rottier et al. 1981b, Morser and Lomniczi to be published). During a chase period after pulse labelling late in infection there is relatively little export of newly synthesized nucleocapsid protein from the cell, indicating that a large intracellular pool builds up early in infection (Anderson et al. 1979, Siddell et al. 1981b, Rottier et al. 1981b, Holmes et al. 1981, Bond et al. 1981, Morser and Lomniczi to be published). Like other positive-stranded viruses, it seems likely that the majority of this pool would be associated with the EDTAresistant, presumably nucleocapsid structures isolated from infected cells (Bond et al. 1979, Spaan et al. 1981). There are, however, no reports on the rate at which newly synthesized nucleocapsid protein is transferred to nucleocapsid structures; there is also no information on the specificity of nucleocapsid-protein binding to genomic RNA, the nature of the assembly process, or the quantities of nucleocapsid assembled and released from the cell. It is surprising that there have only been two reports of electron microscopic visualization of intracellular structures, tentatively identified as coronavirus nucleocapsids (Caul et al. 1979, Holmes and Behnke 1981).

Several authors have described intracellular polypeptides with similar, but slightly lower molecular weights than the nucleocapsid protein (Table 5). In MHV-infected cells it has been shown that these species are arginine-rich (Anderson et al. 1979), and Cleveland mapping of an analogous protein in IBV-infected cells (Stern et al. 1981) supports the conclusion that these species are degradation products of the nucleocapsid protein. The intracellular species are not incorporated into virions, but immunoprecipitation of ${ }^{32} \mathrm{P}$-phosphorus-labelled MHV-A59 virions results in the production of phosphorylated polypeptides of a similar size (Rottier et al. 1981a).

A second polypeptide that is consistently found after short-pulse labelling of coronavirus-infected cells has mol. wt. of 20 000-30000 and is immunoprecipitable with hyperimmune serum (Table 5). Studies in MHV-infected cells during a chase period show that a further one or more immunoprecipitable polypeptides of slightly higher molecular weight, corresponding in size to the low molecular weight virion glycoprotein(s), become labelled and are exported from the cell together with the smaller polypeptide (Siddell et al. 1981b, Rottier et al. 1981b, Holmes et al. 1981).

These labelling kinetics are consistent with the synthesis of a nonglycosylated primary translation product, which is subsequently post-translationally glycosylated (in some cases to differing degrees) before incorporation into virions. This scheme is supported by the finding that the processed polypeptides, but not the primary translation product, are glycosylated (Holmes et al. 1981, Rottier et al. 1981b, Niemann and Klenk1981) and in vitro translation studies demonstrating the size of the nonglycosylated in vitro translation product to be the same as the primary translation product found in infected 
cells (see Sect. 3.4.2). Furthermore, two-dimensional NEPHGE demonstrates that all of the relevant intracellular species detected have a similar basic charge, as expected if they are related (Siddell et al. 1981b), and preliminary tryptic peptide fingerprinting shows that the low molecular weight IBV-virion polypeptides have related primary structures (Stern et al. 1981) (see Sect. 2.2.1.1). Tryptic peptide fingerprinting of the intracellular polypeptides has not been reported.

As already mentioned, the glycosylation of the coronavirion M protein is not sensitive to inhibition by tunicamycin and, as expected, the intracellular processing events described here are also insensitive to tunicamycin (Siddell et al. 1981c, Rottier et al. 1981b, Holmes et al. 1981, Niemann and Klenk 1981). Clearly, the events involved in the glycosylation of this protein cannot exactly parallel the pattern known for other viral glycoproteins (Wirth et al. 1977, Garoff et al. 1978). However, Siddell et al. (1981b) have shown that during processing of the MHV-JHM protein a short basic polypeptide sequence, which may correspond to a signal sequence, is cleaved from the primary translation product prior to glycosylation.

Immunofluorescent studies with monospecific antiserum against MHV-A59 M protein (Doller and Holmes 1980, Holmes et al. 1981) show that, in contrast to the usual cytoplasmic distribution of envelope glycoproteins (including the coronavirus peplomer protein), the coronavirus $M$ protein is localized to tight clusters in the perinuclear area of infected cells. It is this localization which probably dictates the site of virion budding (see Sect. 3.5) at the rough endoplasmic reticulum and Golgi complex, but it is not known how it correlates with the unusual glycosylation of the protein.

The third major polypeptide detected by pulse-labelling coronavirus-infected cells is a high molecular weight polypeptide which is immunoprecipitable with hyperimmune antiserum and almost certainly corresponds to the intracellular precursor of the virion peplomer protein (Table 5). Sturman and co-workers have proposed a model for the genesis of the MHV-A59 peplomer protein (Sturman 1981, Holmes et al. 1981) in which the intracellular polypeptide is synthesized as a 180000 mol. wt. species which is cotranslationally glycosylated (Holmes et al. 1981). The protein is subsequently incorporated into virions, concomitant with cleavage of a proportion of the molecules, to yield two polypeptides of equal size (i.e., 90000 mol. wt.) but different primary structures.

Data that are consistent with this model are the tryptic peptide fingerprints of the MHV-A59 virion gp $180^{\mathrm{p}}$ and $\mathrm{gp} 90^{\mathrm{p}}$ species, which are identical (Sturman and Holmes 1977), and preliminary tryptic peptide fingerprints of the IBV peplomer proteins $g p 90^{p}$ and gp $84^{\mathrm{p}}$, which show different primary structures (Stern et al. 1981). The IBV polypeptides could be accommodated in the model as the two dissimilar cleavage products of a larger precursor, represented by the $165 \mathrm{~K}$ ( $\mathrm{K}$ is used to denote molecular weight $\times 1000$ ) or 150K species found in infected cells (Stern et al. 1981, Morser and Lomniczi to be published). It has also been reported that proteolytic cleavage of the MHV-A59 virion peplomer protein can be achieved in vitro using trypsin and that the products can be distinguished (Sturman and Holmes 1977, Sturman 1981).

On the other hand, Siddell et al. (1980,1981b), van der Zeijst et al. (1981), Rottier et al. (1981b), and Morserand Lomniczi (to be published) have all reported that the immunoprecipitable peplomer precursor in MHV- or IBV-infected cells is mol. wt. 150000 , which is considerably smaller than the larger virion species. During a chase period after pulse labelling of MHV-infected cells, Siddell et al. (1981b) and Rottier et al. (1981b) detected the disappearance of the $150 \mathrm{~K}$ species and the appearance in the cell of immunoprecipitable 
$170 \mathrm{~K}$ and $90 / 98 \mathrm{~K}$ species, i.e., the same as the virion proteins. When analysed on twodimensional gels these species were found to be acidic and heterogeneously charged (Siddell et al. 1981b). While these data are not incompatible with the Sturman model, they do indicate that more experiments will have to be performed before the synthesis and processing of these proteins can be accurately described.

The intracellular peplomer precursor is glycosylated (Bond et al. 1979, Anderson et al. 1979, Rottier et al. 1981b, Niemann and Klenk 1981) and, in contrast to the coronavirus M protein, glycosylation is inhibited by tunicamycin (Niemann and Klenk 1981) indicating $\mathrm{N}$-glycosidic oligosaccharide linkages (see Sect. 2.2.1.2). A putative apoprotein that is immunoprecipitable with hyperimmune serum has been identified in MHV-infected cells treated with tunicamycin (Siddell et al. 1981c, Rottier et al. 1981a, 1981b). The apoprotein, which is apparently unstable (Rottier et al. 1981b), is $110000-120000 \mathrm{~mol}$. wt. In vitro translation studies (see Sect. 3.4.2) also suggest this to be the size of the nonglycosylated peptide core of the peplomer precursor.

As well as the polypeptides described above, Table 5 lists a number of intracellular proteins which have been described as virus-specific. Those described by Siddell et al. (1981b) are labelled by short pulses and have been shown to be specific to infected cells by two-dimensional PAGE. One of them (the $65 \mathrm{~K}$ species) is immunoprecipitated by hyperimmune serum and coelectrophoreses with a virion protein. A protein of comparable size (55K) has also been specifically immunoprecipitated from IBV-infected cells (Morser and Lomniczi, to be published).

Although the $30 \mathrm{~K}$ and $14 \mathrm{~K}$ species found in MHV-JHM-infected cells (Siddell et al. 1981c) are not immunoprecipitable with antiserum, there is evidence from in vitro translation studies to support their virus specificity (see Sect. 3.4.2). Also, Rottier et al. (1981b) detected a minor polypeptide of $14.5 \mathrm{~K}$ in MHV-A59-infected cells which is, however, immunoprecipitable and has virion counterpart (see Sect. 2.2.1.1). The origins or virus specificities of the remaining polypeptides listed in Table 5 are not yet clear.

\subsubsection{In Vitro}

Coronavirus RNA has been isolated from MHV-infected cells, and in one case MHV virions, and translated in vitro using cell-free systems or by injection into oocytes (Siddell et al. 1980, 1981c, Rottier et al. 1981a, Leibowitz and Weiss 1981). Using gel electrophoresis, immunoprecipitation, and tryptic peptide fingerprinting it has been possible to identify the in vitro translation products as virus-specific and correlate them to proteins found in MHV virions or infected cells. The virus-specific mRNA has also been fractionated before translation and preliminary coding assignments have been made for the subgenomic viral RNA species found in infected cells (Table 6).

Siddell et al. $(1980,1981 c)$ isolated cytoplasmic poly A-containing RNA from MHVJHM-infected cells and translated it in nuclease-treated cell-free systems from $L$ cells and rabbit reticulocytes. Among the products, the $60 \mathrm{~K}$ nucleocapsid protein and the $23 \mathrm{~K}$ nonglycosylated precursor to the virion $\mathrm{M}$ protein could be identified by electrophoresis, immunoprecipitation, and tryptic peptide fingerprinting. Additionally, a 120K product was identified as virus-specific by immunoprecipitation and most probably corresponds to the peplomer apoprotein described in the previous section. Subsequently, by fractionating the cytoplasmic poly A RNA species in sucrose formamide gradients the same authors were able to assign the translation activities encoding these proteins to RNA 7,6, 
Table 6. Coding assignments for MHV-RNA

\begin{tabular}{|c|c|c|c|}
\hline Reference & Leibowitz and Weiss (1981) & Rottier et al. (1981a) & Siddell et al. $(1980,1981 c)$ \\
\hline Virus & MHV-A59 & MHV-A59 & MHV-JHM \\
\hline System & Reticulocyte lysate & $X$. laevis oocyte & $L$ cell, reticulocyte lysate \\
\hline RNA genome (1) & $\mathrm{NSA}^{\mathrm{d}}(200 \mathrm{~K})^{\mathrm{a}}$ & - & - \\
\hline RNA 2 & - & - & $\mathrm{NSB}^{\mathrm{d}}(30 \mathrm{~K})$ \\
\hline RNA 3 & - & $\begin{array}{l}\text { Peplomer precursor } \\
(150 \mathrm{~K})\end{array}$ & $\begin{array}{l}\text { Peplomer apoprotein } \\
(120 \mathrm{~K})\end{array}$ \\
\hline RNA 4 & - & - & $N S D-E^{d}(14 K)^{b}$ \\
\hline $\begin{array}{l}\text { RNA } 5 \\
\text { RNA } 6\end{array}$ & $\overline{\text { Matrix nrecursor }}$ & $\bar{M}$ Matrix protein & Matrix precursor \\
\hline RNA 6 & $\begin{array}{l}\text { Matrix precursor } \\
(23 K)^{\mathrm{c}}\end{array}$ & $(24-26.5 K)^{c}$ & $(23 K)$ \\
\hline RNA 7 & Nucleocapsid & Nucleocapsid (54K) & Nucleocapsid (60K) \\
\hline
\end{tabular}

${ }^{a}$ Also MHV-JHM RNA; ${ }^{b}$ The precise assignment of this product cannot yet be made; ${ }^{c}$ This RNA also directed the synthesis of small amounts of nucleocapsid protein, probably due to contamination or RNA degradation; ${ }^{\mathrm{d}}$ These proteins are tentatively designated NS and identified as the product of gene A, B, and D-E (see Fig. 3)

and 3, respectively (Siddell et al. 1981c). Also, using size-fractionated RNA, the in vitro synthesis of $30 \mathrm{~K}$ and $14 \mathrm{~K}$ polypeptides, which coelectrophorese with virus-specific proteins in infected cells (see Sect. 3.4.1) could be detected and the translational activities assigned to RNA 2 and 4-5.

In a similar study using purified RNA recovered from agarose gels, Rottier et al. (1981a) reached identical conclusions regarding the assignment of RNA 7, 6, and 3 as the mRNA-encoding nucleocapsid, $M$, and peplomer proteins, respectively. In this study the RNAs were injected into Xenopus laevis oocytes and, as the oocytes are capable of certain post-translational modifications, the in vitro products, which could be identified by electrophoresis and immunoprecipitation, corresponded to their glycosylated counterparts in infected cells.

Consistent with these results, Leibowitz and Weiss (1981) also purified MHV-A59 7 and 6 in agarose gels and translated them in reticulocyte lysates. The products were identified, by electrophoresis and tryptic peptide mapping, as nucleocapsid and $\mathrm{M}$ precursor proteins, respectively. In addition, these authors isolated RNA from MHV virions and translated it, again in reticulocyte lysates. In this case, three structurally related polypeptides of greater than $200000 \mathrm{~mol}$. wt. were detected. These polypeptides do not correspond in size to any known MHV-specific proteins and corresponding proteins have not been found in infected cells.

\subsubsection{Replication Strategy}

The data reviewed in the previous sections suggest that coronaviruses display a different replication strategy to those previously described for other positive-stranded viruses. The essential features of the strategy are as follows: 1) The expression of coronavirus information in the cell is mediated through multiple subgenomic RNA that share common sequences at their $3^{\prime}$ ends and form a nested set extending inwards toward the $5^{\prime}$ end of the 
152 St. Siddell et al.

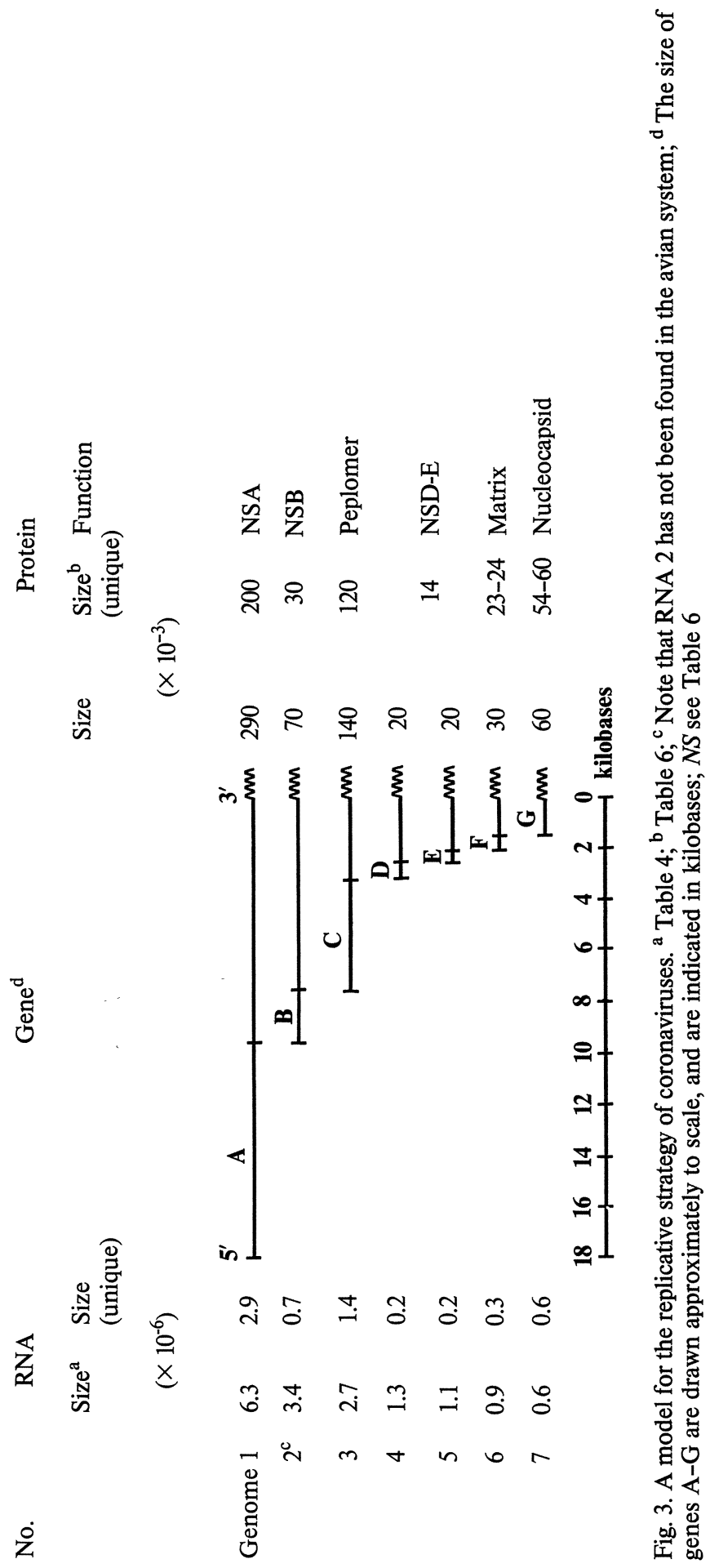


genome; 2) Each mRNA directs the translation of only one protein; 3) The size of the translation product for each mRNA corresponds approximately to the coding potential of the $5^{\prime}$ terminal sequences which are absent from the next-smallest mRNA.

Eukaryotic mRNAs are thought to have only one active initiation site at the $5^{\prime}$ terminus (Kozak 1978) and, if it is assumed that internal initiation does not occur on coronavirus mRNA, these data can be interpreted in the model depicted in Fig. 3. In this model, each mRNA acts monocistronically and only the $5^{\prime}$ terminal sequences (described as gene A, B, etc.) are translated into protein. It can be seen that there is an acceptable agreement between the size of the predicted translation product for each mRNA and the virus-specific protein assigned to it. Verification of this model will require sequence analyses of coronavirus nucleic acid and proteins. Such studies may indicate additional complexities that need not yet be postulated, though the essential features of the model will probably hold true.

The strategy depicted in Fig. 3 contains novel features, but also has parallels with the strategies employed by other positive-stranded viruses, such as alpha-viruses and certain plant viruses (Fraenkel-Conrat et al. 1977, Kääriänen and Söderlund1978): For example, it appears that all subgenomic mRNAs must extend inward from the $3^{\prime}$ end of the genomes. We are not aware of a physiological polyadenylated mRNA which contains sequences from the $5^{\prime}$, but not $3^{\prime}$ end of a positive-stranded genome. Whether this observation reflects evolutionary relationships or constraints imposed by the replicative mechanism of the viral mRNA is not clear.

On the other hand, in contrast to alpha-viruses, coronavirus mRNAs appear to function monocistronically and do not direct the synthesis of polyprotein precursors. Also, in contrast to recent reports for influenza virus (Inglis et al. 1979, Lamb et al. 1980), there is no evidence to suggest that coronavirus proteins are encoded in overlapping sequences, either in the same or different reading frames.

A number of advantages to the coronavirus replication strategy can be seen. Firstly, the strategy appears to be a particularly flexible one, allowing for the control of viral protein synthesis at the levels of both transcription and translation. Secondly, this strategy would be compatible with a need to separate the translation and post-translational modifications of different viral polypeptides into different cellular compartments, perhaps as exemplified by the virus-envelope proteins. At the same time, it should be noted that the coronavirus strategy does not appear to be particularly economical. A simple calculation shows that, in the model described, almost $60 \%$ of the sequence information expressed in mRNA appears redundant. Although the coronavirus genome is the largest yet described for an animal RNA virus and events with such obvious advantages as mRNA splicing also seem uneconomical, this observation prompts the question of whether the strategy described here may be more complex than it first appears.

No mention of the use of ts or other coronavirus mutants as biochemical probes has been made in this review. $R o b b$ et al. (1979) performed some preliminary characterizations of a large number of MHV-JHM ts mutants and it has recently become possible to order these mutants into RNA-positive and RNA-negative groups belonging to one of seven complementation groups (Leibowitz, personal communication). The importance of these mutants in analyzing the details of coronavirus replication are obvious. 


\subsection{Virion Assembly}

Morphogenetic studies on the maturation of coronaviruses have been described (McIntosh 1974, Doughri et al. 1976; Caul and Egglestone 1977, Massalski et al. 1981, Holmes and Behnke 1981, Ducatelle et al. 1981). Briefly, assembly is restricted to the cytoplasm where progeny virions are formed by a budding process from membranes of the rough endoplasmic reticulum (Massalski et al. 1981, Holmes and Behnke 1981). The virions acquire their lipid membranes from the cell, excluding host-cell proteins in the process, and are subsequently transported through and accumulate in Golgi complex and smooth-walled vesicles. There is an absence of budding from the plasmalemma and virions are released from the cell by lysis of plasma and/or endoreticular membranes, or by fusion of virus containing vesicles with the plasmalemma. The studies of Doller and Holmes 1980 and Holmes and Behnke (1981) suggest that the site of virion budding at the rough endoplasmic reticulum is determined by a transmembrane interaction between the virion $\mathrm{M}$ protein and the peplomer protein. The peplomer protein is associated with the transport and secretion of the virions from the cell.

Yoshikura and Taguchi (1978) show prelimiary evidence that simultaneous infection of mouse tissue culture cells with MHV-S and Friend leukemia virus (FLV) can result in phenotypic mixing, i.e., the coronavirus genotype within the FLV envelope. This observation would indicate that the nucleocapsid-M protein-peplomer protein interaction is not absolutely specific, and the budding of coronavirus nucleocapsids at the plasmalemma may be possible.

\section{Persistent Infection}

In contrast to other positive-stranded viruses, coronaviruses tend to establish persistent infection in tissue culture, and Table 7 lists the persistent infections that have been established to date. Mechanisms which could conceivably play a role in the establishment of a persistent coronavirus infection include the integration of virus sequences into the hostcell DNA, episome formation, the establishment of ts or poorly growing mutants that conditionally interfere with the replication of non-ts virus, defective interfering virus, and interferon production.

At present there is no reason to favor or disfavor any of these alternatives as important in coronavirus persistent infection. Robb and Bond (1979a) have reported that coronaviruses may produce defective, although apparently noninterfering virus in tissue culture, and several authors (Table 7) have demonstrated the development of ts and small-plaque mutants in persistent coronavirus infections. As there is no reason to believe that only one mechanism need be operative, only further biochemical comparison between persistent and cytolytic coronavirus infections will shed light on this question.

\section{Conclusions}

There has been a significant advance in our understanding of the structure and replication of coronaviruses in the last 2 years. However, there are still enormous gaps in our knowledge. Figure 4 depicts a hypothetical scheme describing the possible events involved in coronavirus replication and, by considering the phases of the cycle, the extent of our understanding can be gauged. 
Table 7. Persistent coronavirus infection in tissue culture (see also Sabesin 1972, Yoshikura and Taguchi 1978)

\begin{tabular}{|c|c|c|c|c|c|c|c|c|}
\hline \multirow{3}{*}{$\begin{array}{l}\text { Virus } \\
\text { (cell) } \\
\text { MHV-A59 } \\
(17 \mathrm{C} 11)\end{array}$} & \multicolumn{4}{|c|}{ Properties of persistent cell lines } & \multicolumn{4}{|c|}{ Properties of the virus References } \\
\hline & $\begin{array}{l}\text { Cells with } \\
\text { antigen } \\
(\%)\end{array}$ & $\begin{array}{l}\text { Infectious } \\
\text { virus }\end{array}$ & $\begin{array}{l}\text { Infec } \\
\text { resist } \\
\text { corona }\end{array}$ & $\begin{array}{l}\text { tion } \\
\text { tence } \\
\text { a/other }\end{array}$ & ts & Non-ts & $\begin{array}{l}\text { Altered } \\
\text { plaque }\end{array}$ & \\
\hline & $10-20$ & + & + & - & $t^{\mathrm{a}}$ & $+t^{b}$ & $+^{\mathrm{b}}$ & $\begin{array}{l}\text { Holmes and Behnke } \\
\text { (1981) }\end{array}$ \\
\hline $\begin{array}{l}\text { MHV-JHM } \\
\left(\mathrm{N}_{2} \mathrm{~A}\right)\end{array}$ & $80-100$ & + & + & $+1-$ & + & - & - & $\begin{array}{l}\text { Stohlman et al. } \\
(1978) \\
\text { Stohlman et al. } \\
(1979 \mathrm{a}, \mathrm{b}) \\
\text { Stohlman and } \\
\text { Weiner }(1978)\end{array}$ \\
\hline $\begin{array}{l}\text { MHV-JHM } \\
\left(\mathrm{N}_{2} \mathrm{~A}\right)\end{array}$ & ND & + & ND & - & + & - & ND & $\begin{array}{l}\text { Robb and Bond } \\
\text { (1979a) }\end{array}$ \\
\hline $\begin{array}{l}\text { MHV-A59-JHM } \\
(17 \mathrm{C} 11)\end{array}$ & ND & + & + & $+1-$ & + & - & ND & $\begin{array}{l}\text { Robb and Bond } \\
(1979 \mathrm{a})\end{array}$ \\
\hline $\begin{array}{l}\text { MHV-JHM } \\
\text { (RN 2-2) }\end{array}$ & 1 & + & + & $+1-$ & - & + & - & $\begin{array}{l}\text { Lucas et al. (1977, } \\
\text { 1978c) } \\
\text { Sorensen et al. (1981) }\end{array}$ \\
\hline $\begin{array}{l}\text { MHV-JHM } \\
\text { (DBT) }\end{array}$ & $10-15$ & + & + & - & - & - & + & Hirano et al. (1981) \\
\hline $\begin{array}{l}\text { HCV-229E } \\
\text { (L132) }\end{array}$ & ND & + & + & - & - & - & + & $\begin{array}{l}\text { Chaloner-Larsson } \\
\text { and Johnson- } \\
\text { Lussenburg } \\
\text { (1981a, 1981b) }\end{array}$ \\
\hline
\end{tabular}

${ }^{a}$ Early passages; ${ }^{b}$ Late passages; ${ }^{\mathrm{c}}$ These authors have established, but not characterized, MHV persistent infections in oligodendroglioma, neuroblastoma, myoblast, and hepatoma cell lines

Perhaps the greatest lack of information concerns the early events associated with infection. To date, the functions of the virion-envelope glycoproteins and the nature of the host-cell receptors have not been determined, and there have been no reported attempts to isolate these receptors by, for example, affinity chromatography. Similarly, the internalization and uncoating of nucleocapsid structures to present the genomic RNA for translation are processes about which essentially nothing is known. Studies with radioactive virus, subcellcular fractionation, and immunological techniques would be most useful.

The virion RNA is depicted in Fig. 4 as encoding protein which are components of a virus-specific RNA polymerase. The synthesis of any such protein in the infected cell has not been detected and, although manifestly present it has proven difficult to isolate any RNA polymerase activity in vitro. Consequently, attempts to purify the enzyme and identify its polypeptide components and enzymic functions have been thwarted. The involvement of a host-cell nuclear function in the activity of this enzyme is a further possibility, although in view of the available evidence an improbable refinement.

After the initial phase of viral RNA translation, sufficient RNA polymerase is accumulated to form a replicative structure that is initially responsible for its own amplifi- 


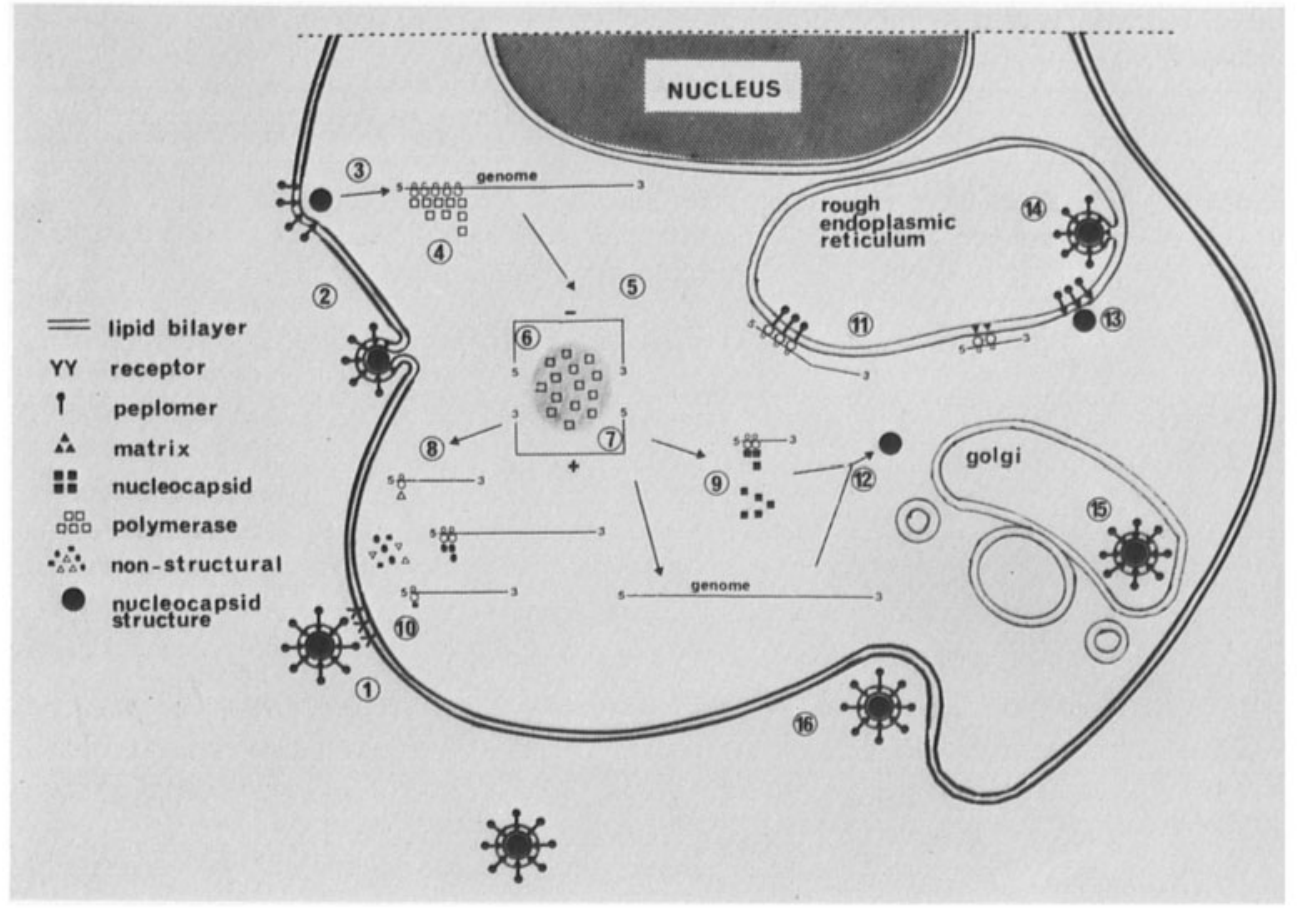

Fig. 4. A hypothetical scheme for coronavirus replication. Virus adsorbs to specific receptors at the plasmalemma (ㄷ) and it is internalized (2). The nucleocapsid is uncoated (3) and translated to produce components of the polymerase (ब). When enough polymerase is formed, translation of the virion RNA is replaced by the formation of a replicative structure (5), which produces genomesized negative-stranded RNA (ङ) and from which further genome-sized positive RNA can be produced (ㄱ), to repeat and amplify steps (๑)-(). Subsequently, subgenomic mRNAs are produced (ङ). The translation of the nucleocapsid protein (๑) and nonstructural proteins (미) occurs on free polyribosomes and the envelope proteins, translated on membrane-bound polyribosomes (ㅍㄴ: at the rough endoplasmic reticulum, are inserted to the cisternal face and glycosylated. The nucleocapsid protein and progeny virion RNA assemble into nucleocapsid structures (ㄱ) that migrate to the rough endoplasmic reticulum and interact with $\mathrm{M}$ protein (ㅇ) , which itself is associated with virion peplomer protein. The nucleocapsids bud into the cisternae of the rough endoplasmic reticulum (ब), excluding host-cell protein. Virions are then transported, possibly with further modification (glycosylation, peplomer cleavage) through the Golgi complex and smooth-walled vesicles (며) and are released into the medium by reverse viropexis (마)

cation, but subsequently produces virion progeny RNA and mRNA. To date, this replicative structure has not been identified or isolated from infected cells and none of the negative-strand templates which can be assumed to be necessary have been demonstrated. Whether the same or separate enzyme activities are responsible for plus- and minus-strand RNA synthesis is also unknown. Later in infection it is possible to characterize the synthesis of viral mRNA and the translation of virus-specific proteins in the infected cell. This information forms the bulk of the recently available data and, by virtue of these studies and in vitro translation experiments, it has proven possible to provide tentative coding assignments for viral mRNA and produce a genetic map, at least for the murine coronavirus MHV. 
To a large extent the subsequent phases depicted in Fig. 4 assume the paradigms established for other viruses. Any nonstructural viral proteins and the virion capsid protein are assumed to be translated on free polyribosomes, while the synthesis of the envelope glycoprotein is shown as occurring on membrane bound polyribosomes at the rough endoplasmic reticulum (Wirth et al. 1977, Garoff et al. 1978). At the present time these assumptions are supported only by morphogenetic, and not biochemical evidence. After budding, coronaviruses are transported through specific cellular compartments and may undergo further modifications, e.g., polypeptide cleavage and further glycosylation. In view of the unusual properties of coronavirus glycoproteins this aspect of virion maturation deserves special attention. Finally, virions are released from the cell to complete the cycle.

Note added in proof. Anderson and co-workers (Cheley et al. Virology 112:596-604) have isolated mRNA 7 from MHV A59-infected cells and shown that it directs the synthesis of virion nucleocapsid protein in vitro. Randomly primed cDNA prepared from this RNA hybridizes specifically to six polyadenylated intracellular RNA species with sizes of 4.0, 3.0, 1.6, 1.4, 1.1, and $0.8 \times 10^{6}$. The same authors (Cheley and Anderson J Gen Virol 54:301-311) have also concluded that the translation of each major virus structural protein in infected cells is initiated independently, after the removal of a hypertonic salt block. These results are consistent with the replication model described above.

Recently, Lai et al. (personal communication) have shown that the RNAse $\mathrm{T}_{1}$ resistant oligonucleotide which represents the sequence immediately adjacent to the $5^{\prime}$ ends of most, if not all, of the MHV A59 mRNA species, is capped and is identical in each mRNA and in the virion RNA. Sequences adjacent to the "cap" oligonucleotide in each mRNA and the genomic RNA also appear to be closely related (M.M.C. Lai, personal communication; B.A.M. van der Zeijst, personal communication).

Acknowledgements. The authors are supported by the Deutsche Forschungsgemeinschaft and would like to thank Helga Kriesinger for typing the manuscript. We would also like to thank the many colleagues who sent us peprints.

\section{References}

Akashi H, Inaba Y, Miura Y, Sato K, Tokuhisa S, Asagi M, Hayashi Y (1981) Propagation of the Kakegawa strain of bovine coronavirus in suckling mice, rats, and hamsters. Arch Virol 67: $367-370$

Alexander DJ, Collins MS (1975) Effect of $\mathrm{pH}$ on the growth and cytopathogenicity of avian infectious bronchitis virus in chick kidney cells. Arch Virol 49:339-348

Anderson R, Cheley S, Haworth-Hatherell E (1979) Comparison of polypeptides of two strains of murine hepatitis virus. Virology 97:492-494

Apostolov K, Flewett TH, Kendal AP (1970) Morphology of influenza ABC and infectious bronchitis virus (IBV) virions and their replication. In: Barry RD, Mahy BWJ (eds) The Biology of Large RNA Viruses. Academic Press, London, pp 3-26

Bass EP, Sharpee RL (1975) Coronavirus and gastroenteritis in foals. Lancet II, p 822

Bingham RW (1975) The polypeptide composition of avian infectious bronchitis virus. Arch Virol 49:207-216

Bingham RW, Madge MH, Tyrrell DA (1975) Haemagglutination by avian infectious bronchitis virus - a coronavirus. J Gen Virol 28:381-390

Bingham RW, Almeida JD (1977) Studies on the structure of a coronavirus-avian infectious bronchitis virus. J Gen Virol 36:495-502 
Bond CW, Leibowitz JL, Robb JA (1979) Pathogenic murine coronaviruses. II. Characterization of virus-specific proteins of murine coronavirus JHMV and A59V. Virology 94:371-384

Bond CW, Anderson K, Goss S, Sardinia L (1981) Relatedness of virion and intracellular proteins of the murine coronavirus JHM and A59. In: ter Meulen V, Siddell S, Wege H(eds) Biochemistry and Biology of Coronaviruses. Plenum Press, New York, pp 103-110

Brayton PR, Ganges RG, Stohlman SA (1981) Host cell nuclear function and murine hepatitis virus replication. J Gen Virol 56:457-460

Brian DA, Dennis DE, Guy JS (1980) Genome of porcine transmissible gastroenteritis virus. JVirol $34: 410-415$

Bridger JC, Caul EO, Egglestone SI (1978) Replication of an enteric bovine coronavirus in intestinal organ culture. Arch Virol 57:43-51

Callebaut PE, Pensaert MB (1980) Characterization and isolation of structural polypeptides in haemagglutinating encephalomyelitis virus. J Gen Virol 48:193-204

Caul EO, Egglestone SI (1977) Further studies on human enteric coronaviruses. Arch Virol 54: $107-117$

Caul EO, Ashley CR, Ferguson M, Egglestone SJ (1979) Preliminary studies on the isolation of coronavirus 229E nucleocapsids. FEMS Microbiology Letters 5:101-105

Cavanagh D (1981) Structural polypeptides of coronavirus IBV. J Gen Virol 53:93-103

Chaloner-Larsson G, Johnson-Lussenburg CM (1981a) Characteristics of a long-term in vitro persistent infection with human coronavirus 229E. In: ter Meulen V, Siddell S, Wege H (eds) Biochemistry and Biology of Coronaviruses. New York, Plenum Press, pp 309-322

Chaloner-Larsson G, Johnson-Lussenburg CM (1981b) Establishment and maintenance of a persistent infection of L132 cells by human coronavirus strain 229E. Arch Virol 69:117-129

Chasey D, Cartwright SF (1978) Virus-like particles associated with porcine epidemic diarrhoea. Res Vet Sci 25:255-256

Clewley JP, Kennedy SIT (1976) Purification and polypeptide composition of Semliki forest virus RNA polymerase. J Gen Virol 32:395-411

Clewley JP, Morser J, Avery RJ, Lomniczi B (1981) Oligonucleotide fingerprinting of the RNA of different strains of infectious bronchitis virus. Infect Immun 32:1227-1233

Collins MS, Alexander DJ, Harkness JW (1976) Heterogeneity of infectious bronchitis virus genome in eggs. Arch Virol 50:55-72

Collins MS, Alexander DJ (1980a) Avian infectious bronchitis virus structural polypeptides. Effect of different conditions of disruption and comparison of different strains and isolates. Arch Virol 63:239-251

Collins MS, Alexander DJ (1980b) The polypeptide composition of isolated surface projections of avian infectious bronchitis virus. J Gen Virol 48:213-217

Darbyshire JH, Cook JKA, Peters RW (1978) Growth comparisons of avian infectious bronchitis virus strains in organ cultures of chicken tissues. Arch Virol 56:317-325

Davies H, Macnaughton MR (1979) Comparison of the morphology of three coronaviruses. Arch Virol 59:25-33

Davies H, Dourmashkin RR, Macnaughton MR (1981) Ribonucleoprotein of avian infectious bronchitis virus. J Gen Virol 53:67-74

Dea S, Roy BS, Begin ME (1980a) Bovine coronavirus isolation and cultivation in continuous cell lines. Am J Vet Res 41:30-38

Dea S, Roy RS, Begin ME (1980b) Physiochemical and biological properties of neonatal calf diarrhoea coronaviruses isolated in Quebec and comparison with the Nebraska calf coronavirus. Am J Vet Res 41:23-39

Dennis DE, Brian DA (1981) Coronavirus cell-associated RNA-dependent RNA polymerase, In: ter Meulen V, Siddell S, Wege H (eds) Biochemistry and Biology of Coronaviruses. Plenum Press, New York, pp 155-170

Doller EW, Holmes KV (1980) Different intracellular transportation of the envelope glycoproteins E1 and E2 of the coronavirus MHV. Abstracts of the American Society of Microbiology, p 267

Doughri AM, Storz J, Hajer I, Fernando HS (1976) Morphology and morphogenesis of a coronavirus infecting intestinal epithelial cells of newborn calves. Exp Mol Pathol 25:355-370

Ducatelle R, Coussement W, Pensaert MB, Debouck P, Hoorens J(1981) In vivo morphogenesis of a new porcine enteric coronavirus CV777. Arch Virol 68:35-44 
Evans MR, Simpson RW (1980) The coronavirus avian infectious bronchitis virus requires the cell nucleus and host transcriptional factors. Virology 105:582-591

Evermann JF, Baumgartener L, Ott RL, Davis EV, McKeirnan AJ (1981) Characterization of a feline infectious peritonitis virus isolate. Vet Pathol 18:256-265

Fraenkel-Conrat H, Salvato M, Hirth L (1977) The translation of large plant viral RNAs. In: H Fraenkel-Conrat and RR Wagner (eds) Comprehensive Virology. Vol. 11, Plenum Press, New York London

Garoff H, Simons K, Dobberstein B (1978) Assembly of the Semliki forest virus membrane glycoproteins in the membrane of the endoplasmic reticulum in vitro. J Mol Biol 124:587-600

Garwes DJ, Pocock DH (1975) The polypeptide structure of transmissible gastroenteritis virus. J Gen Virol 29:25-34

Garwes DJ, Reynolds DJ (1981) The structure of canine coronavirus and its relationship to porcine transmissible gastroenteritis virus. J Gen Virol 52:153-157

Garwes DJ, Pocock DH, Pike BV (1976) Isolation of subviral components from transmissible gastroenteritis virus. J Gen Virol 32:283-294

Gerdes JC, Jankovsky LD, De Vald BL, Klein I, Burks JS (1981a) Antigenic relationships of coronaviruses detectable by plaque neutralization, competitive enzyme-linked immunoabsorbent assay and immunoprecipitation. In: ter Meulen, V, Siddell, Wege H (eds) Biochemistry and Biology of Coronaviruses. Plenum Press, New York, pp 29-42

Gerdes JC, Klein I, De Vald B, Burks JS (1981b) Coronavirus isolates SK and SD from multiple sclerosis patients are serologically related to murine coronaviruses A59 and JHM and human coronavirus OC43, but not to human coronavirus 229E. J Virol 38:231-238

Gerna G, Torsellini-Gerna M, Gullino M, Cereda P (1975) Maturazione e liberazione di coronavirus (ceppo 229E) in colture di fibroblasti embrionali umani. Giornale di Mallattie Infettive e Parassitivie 27:1121-1124

Gerna G, Achilli G, Cattaneo E, Cereda P (1978a) Determination of coronavirus 229E antibody by an immune adherence haemagglutination method. J Virol Meth 2:215-223

Gerna C, Cattaneo E, Cereda P, Revello MG (1978b) Seroepidemiological study on human coronavirus OC43 infections in Italy. Bollettino Del Instituto Sieroterapi Milanese 57:535-542

Gerna G, Cereda PM, Grazia-Revello M, Cattaneo E, Battaglia M, Torsellini-Gerna M (1981) Antigenic and biological relationships between human coronavirus $\mathrm{OC} 43$ and neonatal calf diarrhoea coronavirus. J Gen Virol 54:91-102

Greig AS, Johnson CM, Bouillant AMP (1971) Encephalitis of swine caused by a haemagglutinating virus. VI. Morphology of the virus. Res Vet Sci 12:305-307

Guy JS, Brian DA (1979) Bovine coronavirus genome. J Virol 29:293-300

Hierholzer JC, Palmer EL, Whitfield SG, Kaye HS, Dowdle WR (1972) Protein composition of coronavirus OC43. Virology 48:516-527

Hierholzer JC (1976). Purification and biophysical properties of human coronavirus 229E. Virology 75:155-165

Hierholzer JC, Kemp MC, Tannock GA (1981) The RNA and proteins of human coronaviruses. In: ter Meulen V, Siddell S, Wege H (eds) Biochemistry and Biology of Coronaviruses. Plenum Press, New York, pp 43-68

Hirai K, Hitchner SB, Calnek BW (1979) Characterization of a new coronavirus - like agent isolated from parrots. Avian Dis 23:515-525

Hirano N, Hino S, Fujiwara K(1978) Physico-chemical properties of mouse hepatitis virus (MHV-2) grown on DBT cell culture. Microbiol Immunol 22:377-390

Hirano N, Goto N, Makino S, Fujiwara K (1981) Persistent infection with mouse hepatitis virus JHM strain in DBT cell culture. In: ter Meulen V, Siddell S, Wege H (eds) Biochemistry and Biology of Coronaviruses. Plenum Press, New York, pp 301-308

Holmes KV, Behnke JN (1981) Evolution of a coronavirus during persistent infection in vitro. In: ter Meulen V, Siddell S, Wege H (eds) Biochemistry and Biology of Coronaviruses. Plenum Press, New York, pp 287-300

Holmes KV, Doller EW, Behnke JN (1981) Analysis of the functions of coronaviruses glycoproteins by differential inhibition of synthesis with tunicamycin. In: ter Meulen V, Siddell S, Wege H (eds) Biochemistry and Biology of Coronaviruses. Plenum Press, New York, pp 133-142

Horvath I, Mocsári E (1981) Ultrastructural changes in the small intestinal epithelium of suckling pigs affected with a transmissible gastroenteritis (TGE)-like disease. Arch Virol 68:103-113 
Hoshino Y, Scott FW (1978) Replication of feline infectious peritonitis virus in organ cultures of feline tissue. Cornell Vet 68:411-417

Inglis SC, Barrett T, Brown CM, Almond JW (1979) The smallest genome RNA segment of influenza virus contains two genes that may overlap. Proc Nat Acad Sci USA 76:3790-3794

Jacobs L, Spaan WJM, Horzinek MC, van der Zeijst BAM (1981) The synthesis of the subgenomic mRNAs of mouse hepatitis virus is initiated independently: evidence from UV transcription mapping. J Virol 39:401-406

Kapikian AZ, James HD Jr, Kelly SJ, King LM, Vaughn AL, Chanock RM (1972) Haemadsorption by coronavirus strain OC43. Proceedings of the Society of Experimental Biology and Medicine 139:179-186

Kääriäinen L, Soederlund H (1978) Structure and replication of alpha-viruses. Curr Top Microbiol Immunol 82:15-70

Kennedy DA, Johnson-Lussenburg CM(1975/1976) Isolation and morphology of the internal component of human coronavirus strain 229E. Intervirology 6:197-206

Klenk HD, Rott R (1981) Cotranslational and posttranslational processing of viral glycoproteins. Curr Top Microbiol Immunol 90:19-48

Kozak M (1978) How do eucaryotic ribosomes select initiation region in messenger RNA? Cell 15:1109-1123

Lai MMC, Stohlman SA (1978) The RNA of mouse hepatitis virus. J Virol 26:236-242

Lai MMC, Stohlman SA (1981a) Comparative analysis of RNA genome of mouse hepatitis viruses. J Virol 38:661-670

Lai MMC, Stohlman SA (1981b) Genome structure of mouse hepatitis virus. Comparative analysis by oligonucleotide mapping. In: ter Meulen V, Siddell S, Wege H (eds) Biochemistry and Biology of Coronaviruses. Plenum Press, New York, pp 69-82

Lai MMC, Brayton PR, Armen RC, Patton CD, Stohlman SA (1981) Mouse hepatitis virus A59 messenger RNA structure and genetic localization of the sequence divergence from the hepatropic strain MHV3. J Virol 39:823-834

Lamb RA, Choppin PW, Chanock RM, Lai CJ (1980) Mapping of the two overlapping genes for polypeptides $\mathrm{NS}_{1}$ and $\mathrm{NS}_{2}$ on RNA segment 8 of influenza virus genome. Proc Nat Acad Sci USA 77:1857-1861

Lanser JA, Howard CR (1980a) The polypeptides of infectious bronchitis virus (IBV-41 strain). J Gen Virol 46:349-361

Lanser JA, Howard CR (1980b) The disruption of infectious bronchitis virus (IBV-41 strain) with Triton X-100 detergent. J Virol Methods 1:121-131

Laporte J, L'Haridon R, Bobulesco P (1980a) In vitro culture of bovine enteric coronavirus. In: INRA Thiverval-Grignon 1979. Bricout F, Scherrer R (eds) Viral Enteritis in Humans and Animals. INSERM, Paris, pp 99-102

Laporte J, Bobulesco P, Rossi $\mathrm{F}$ (1980b) Une lignée cellulaire particulièrement sensible à la réplication du Coronavirus entéritique bovine: les cellules HRT 18. Comptes Rendus Hebdomadaire des Seances de L'Academie des Sciences Série D 290:623-626

Laporte J, Bobulesco P (1981) Polypeptide structure of bovine enteric coronavirus. Comparison between a wild strain purified from feces and a HRTI8 cell-adapted strain. In: ter Meulen V, Siddell S, Wege H (eds) Biochemistry and Biology of Coronaviruses. Plenum Press, New York, pp 181-184

Laude H (1981) Thermal inactivation studies on a coronavirus, transmissible gastroenteritis virus. J Gen Virol 56:235-240

Leibowitz JL, Weiss SR (1981) Murine coronavirus RNA. In: ter Meulen V, Siddell S, Wege H (eds) Biochemistry and Biology of Coronaviruses. Plenum Press, New York, pp 227-244

Leibowitz JL, Wilhelmsen KC, Bond CW (1981) The virus-specific intracellular RNA species of two murine coronaviruses: MHV-A59 and MHV-JHM. Virology 114:39-51

Lomniczi B (1977) Biological properties of avian coronavirus RNA. J Gen Virol 36:531-533

Lomniczi B, Kennedy I (1977) Genome of infectious bronchitis virus. J Virol 24:99-107

Lomniczi B, Morser J (1981) Polypeptides of infectious bronchitis virus. I. Polypeptides of the virion. J Gen Virol 55:155-164

Lucas A, Flintoff W, Anderson R, Percy D, Coulter M, Dales S (1977) In vivo and in vitro models of demyelinating diseases. Tropism of the JHM strain of murine hepatitis virus for cells of neural origin. Cell 12:553-560 
Lucas A, Coulter M, Anderson R, Dales S, Flintoff W (1978) In vivo and in vitro models of demyelinating diseases. Persistence and host-regulated thermosensitivity in cells of neural derivation infected with mouse hepatitis and measles viruses. Virology 88:325-337

McIntosh K (1974) Coronaviruses. A comparative review. Curr Top Microbiol Immunol 63:85-129

Macnaughton MR (1978) The genomes of three coronaviruses. FEBS Lett 94:191-194

Macnaughton MR (1980) The polypeptides of human and mouse coronaviruses. Arch Virol 63: $75-80$

Macnaughton MR (1981) Structural and antigenic relationships between human murine and avian coronaviruses. In: ter Meulen V, Siddell S, Wege $\mathrm{H}$ (eds) The Biology and Biochemistry of Coronaviruses. Plenum Press, New York, pp 19-28

Macnaughton MR, Davies HA (1980) Two particle types of avian infectious bronchitis virus. J Gen Virol 47:365-372

Macnaughton MR, Madge H (1977) The polypeptide composition of avian infectious bronchitis virus particles. Arch Virol 55:47-54

Macnaughton MR, Madge MH (1978) The genome of human coronavirus strain 229E. J Gen Virol 39:497-504

Macnaughton MR, Davies HA, Nermut MV (1978) Ribonucleoprotein-like structures from coronavirus particles. J Gen Virol 39:545-549

Macnaughton MR, Madge MH, Davies HA, Dourmashkin RR (1977) Polypeptides of the surface projections and the ribonucleoprotein of avian infectious bronchitis. J Virol 24:821-825

Macnaughton MR, Thomas BJ, Davies HA, Patterson S (1980) Infectivity of human strain 229E. J Clin Microbiol 12:462-468

Malluci L (1965) Observation on the growth of mouse hepatitis virus (MHV-3) in mouse macrophages. Virology 25:30-37

Massalski A, Coulter-Mackie M, Dales S (1981) Assembly of mouse hepatitis virus strain JHM. In: ter Meulen V, Siddell S, Wege H (eds) Biochemistry and Biology of Coronaviruses. Plenum Press, New York, pp 111-118

Monto AS, Rhodes LM (1977) Detection of coronavirus infection of man by immunofluorescence. Proc Soc Exp Biol Med 155:143-148

Morser J, Lomniczi B (to be published) Polypeptides of infectious bronchitis virus. II. Polypeptides synthesized in infected cells.

Niemann H, Klenk HD (1981) Glycoprotein E1 of coronavirus A59. A new type of viral glycoprotein. In: ter Meulen V, Siddell S, Wege H (eds) Biochemistry and Biology of Coronaviruses. Plenum Press, New York, pp 119-132

Obert G, Grollemund E, Nonnenmacher H, Kirn A (1981) Analysis and localization of mouse hepatitis virus 3 (MHV3) polypeptides. Ann Virol [Inst Pasteur] 132E:109-114

O'Reilly KJ, Fishman B, Hitchcock LM (1979) Feline infectious peritonitis. Isolation of a coronavirus. Vet Rec 104:348

Patterson S, Bingham RW (1976) Electron microscope observations on the entry of avian infectious bronchitis virus into susceptible cells. Arch Virol 52:191-200

Patterson S, Macnaughton MR (1981) The distribution of human coronavirus strain 229E on the surface of human diploid cells. J Gen Virol 53:267-273

Pedersen NC, Ward I, Mengeling WL (1978) Antigenic relationship of the feline infectious peritonitis virus to coronaviruses of other species. Arch Virol 58:45-53

Pensaert M, Callebaut $\mathrm{P}(1978)$ The coronaviruses. Clinical and structural aspects with some practical implications. Ann Méd Vét 122:301-322

Pensaert MB, Debouck P (1978) A new coronavirus-like particle associated with diarrhoea in swine. Arch Virol 58:243-247

Pike BV, Garwes DJ (1977) Lipids of transmissible gastroenteritis virus and their relation to those of two different host cells. J Gen Virol 34:531-535

Pocock DH (1978) Effect of sulphydryl reagents on the biological activities, polypeptide composition, and morphology of haemagglutinating encephylomyelitis virus. J Gen Virol 40:93-101

Pocock DH, Garwes DJ (1975) The influence of pH on the growth and stability of transmissible gastroenteritis virus. Arch Virol 49:239-247

Pocock DH, Garwes DJ (1977) The polypeptides of haemagglutinating encephalomyelitis virus and isolated subviral particles. J Gen Vir 37:487-499 
Robb JA, Bond CW (1979a) Coronaviridae. vol 14. In: Fraenkel-Conrat H, Wagner RR (eds) Comprehensive Virology. Plenum Press, New York, pp 193-247

Robb JA, Bond CW (1979b) Pathogenic murine coronaviruses. I. Characterization of biological behaviour in vitro and virus-specific intracellular RNA of strongly neurotropic JHMV and weakly neurotropic A59V viruses. Virology 94:352-370

Robb JA, Bond CW, Leibowitz JL (1979) Pathogenic murine coronaviruses. III. Biological and biochemical characterization of temperature-sensitive mutants of JHMV. Virology 94:385-399

Rottier PJM, Spaan WJM, Horzinek M, van der Zeijst BAM (1981a) Translation of three mouse hepatitis virus (MHV-A59) subgenomic RNAs in Xenopus laevis oocytes. J Virol 38:20-26

Rottier PJM, Horzinek MC, van der Zeijst BAM (1981b) Viral protein synthesis in mouse hepatitis virus train A59-infected cells: effect of Tunicamycin. J Virol 40:350-357

Sabesin SM (1972) Isolation of a latent murine hepatitis virus from cultured mouse liver cells. Am J Gastroenterol 58:259-274

Schmidt OW, Cooney MK, Kenny GE (1979) Plaque assay and improved yield of human coronaviruses in a human rhabdosarcoma cell line. J Clin Microbiol 9:722-728

Schochetman G, Stevens RH, Simpson RW (1977) Presence of infectious polyadenylated RNA in the coronavirus avian infectious bronchitis virus. Virology 77:772-782

Siddell SG, Wege H, Barthel A, ter Meulen V (1980) Coronavirus JHM. Cell-free synthesis of structural protein p60. J Virol 33:10-17

Siddell SG, Barthel A, ter Meulen V (1981a) Coronavirus JHM. A virion-associated protein kinase. J Gen Virol 52:235-243

Siddell SG, Wege H, Barthel A, ter Meulen V (1981b) Coronavirus JHM. Intracellular protein synthesis. J Gen Virol 53:145-155

Siddell S, Wege H, Barthel A, ter Meulen V (1981c) Intracellular protein synthesis and the in vitro translation of coronavirus JHM mRNA. In: ter Meulen V, Siddell S, Wege H (eds) Biochemistry and Biology of Coronaviruses. Plenum Press, New York, pp 193-208

Sorensen O, Coulter-Makie M, Percy D, Dales S (1981) In vivo and in vitro models of demyelinating diseases, In: ter Meulen V, Siddell S, Wege H (eds) The Biology and Biochemistry of Coronaviruses. Plenum Press, New York, pp 271-286

Spaan WJ, Rottier PJM, Horzinek MC, van der Zeijst BAM (1981) Isolation and identification of virus-specific mRNAs in cells infected with mouse hepatitis virus (MHV-A59). Virology 108: 424-434

Stair EL, Rhodes MB, White RG, Mebus CA (1972) Neonatal calf diarrhoea. Purification and electron microscopy of a coronavirus-like agent. Am J Vet Res 33:1147-1156

Stern DF, Kennedy SIT (1980a) Coronavirus multiplication strategy. I. Identification and characterization of virus-specified RNA. J Virol 34:665-674

Stern DF, Kennedy SIT (1980b) Coronavirus multiplication strategy. II. Mapping the avian infectious bronchitis virus intracellular RNA species to the genome. J Virol 36:440-449

Stern D, Burgess L, Linesch S, Kennedy I (1981) The avian coronavirus multiplication strategy. In: ter Meulen V, Siddell S, Wege H(eds) Biochemistry and Biology of Coronaviruses. Plenum Press, New York, pp 185-192

Stohlman SA, Weiner LP (1978) Stability of neurotropic mouse hepatitis virus (JHM strain) during chronic infection of neuroblastoma cells. Arch Virol 57:53-61

Stohlman SA, Sakaguchi AY, Hiti A (1978) Interferon production and activity in mouse neuroblastoma cells. Arch Virol 57:91-96

Stohlman SA, Lai MMC (1979) Phosphoproteins of murine hepatitis viruses. J Virol 32:672-675

Stohlman SA, Sakaguchi AY, Weiner LP (1979a) Rescue of a positive-stranded RNA virus from antigen-negative neuroplastoma cells. Life Sci 24:1029-1036

Stohlman SA, Sakaguchi AY, Weiner LP (1979b) Characterization of the cold-sensitive murine hepatitis virus mutants rescued from latently infected cells by cell fusion. Virology 98:448-455

Stohlman SA, Lai MMC, Weiner LP (to be published) Murine coronaviruses. Isolation and characterization of two plaque morphology variants of a neurotropic strain JHM.

Storz J, Kaluza G, Niemann H, Rott R (1981a) On enteropathogenic bovine coronavirus. In: ter Meulen V, Siddell S, Wege H (eds) Biochemistry and Biology of Coronaviruses. Plenum Press, New York, pp 171-180

Storz J, Rott R, Kaluza G (1981b) Enhancement of plaque formation and cell fusion of an enteropathogenic coronavirus by trypsin treatment. Infect Immun 31:1214-1222 
Sturman LS (1977) Characterization of a coronavirus. I. Structural proteins: effects of preparative conditions on the migration of protein in polyacrylamide gels. Virology 77:637-649

Sturman LS, Holmes KV (1977) Characterization of a coronavirus. II. Glycoproteins of the viral envelope: tryptic peptide analysis. Virology 77:650-660

Sturman LS, Holmes KV, Behnke J (1980) Isolation of coronavirus envelope glycoproteins and interaction with the viral nucleocapsid. J Virol 33:449-462

Sturman LS (1981) The structure and behaviour of coronavirus A 59 glycoprotein: In: ter Meulen V, Siddell S, Wege H (eds) Biochemistry and Biology of Coronaviruses. Plenum Press, New York, pp 1-18

Sugiyama K, Amano Y (1980) Haemagglutination and structural polypeptides of a new coronavirus associated with diarrhoea in infant mice. Arch Virol 66:95-105

Sugiyama K, Amano Y (1981) Morphology and biological properties of a new coronavirus associated with diarrhoea in infant mice. Arch Virol 67:241-251

Taguchi F, Hayashi T, Yamada A, Fujiwara K (1978) Purification and buoyant density of a mouse hepatitis virus MHV-S. Jpn J Exp Med 48:369-371

Tannock CA, Hierholzer JC (1978) Presence of genomic polyadenylate and absence of detectable virion transcriptase in human coronavirus OC43. J Gen Virol 39:29-39

Testa D, Chanda PK, Banerjee AK (1980) Unique mode of transcription in vitro by vesicular stomatitis virus. Cell 21:267-275

Tyrrell DAJ, Almeida JD, Berry DM, Cunningham CH, Hamre D, Hofstad MS, Mallucci L, McIntosh K (1968) Coronaviruses. Nature 220:650

Tyrrell DAJ, Alexander DJ, Almeida JD, Cunningham CH, Easterday BC, Garwes DJ, Hierholzer JC, Kapikian A, Macnaughton MR, McIntosh K (1978) Coronaviridae. 2nd report. Intervirology 10:321-328

Waday CN, Westaway EG (1981) Structural proteins and glycoproteins of infectious bronchitis virus particles labelled during growth in chick embryo fibroblasts. Intervirology 15:19-27

Walker DP, Cleator GM (1980) Haemagglutination by mouse hepatitis virus type 3. Ann Virol [Inst Pasteur] 131E:517-520

Wege H, Müller A, ter Meulen V (1978) Genomic RNA of the murine coronavirus JHM. J Gen Virol 41:217-227

Wege H, Wege Hanna, Nagashima K, ter Meulen V (1979) Structural polypeptides of the murine coronavirus JHM. J Gen Virol 42:37-47

Wege H, Stephenson JR, Koga M, Wege Hanna, ter Meulen V (1981a) Genetic variation of neurotropic and non-neurotropic murine coronaviruses. J Gen Virol 54:67-74

Wege H, Siddell S, Sturm M, ter Meulen V (1981b) Coronavirus JHM: characterization of intracellular viral RNA. J Gen Virol 54:213-217

Wege H, Siddell S, Sturm M, ter Meulen V (1981c) Characterization of viral RNA in cells infected with the murine coronavirus JHM. In: ter Meulen V, Siddell S, Wege H (eds) Biochemistry and Biology of Coronaviruses. Plenum Press, New York, pp 91-102

Weiss SR, Leibowitz JL (1981) Comparison of the RNAs of murine and human coronaviruses. In: ter Meulen V, Siddell S, Wege H (eds) Biochemistry and Biology of Coronaviruses. Plenum Press, New York, pp 245-260

Wilhelmsen KC, Leibowitz JL, Bond CW, Robb JA(1981) The replication of murine coronaviruses in enucleated cells. Virology 110:225-230

Wirth DF, Katz F, Small B, Lodish HF (1977) How a single Sinbis virus mRNA directs the synthesis of one soluble protein and two integral membrane glycoproteins. Cell 10:253-263

Yogo Y, Hirano N, Hino S, Shibuta H, Matumoto M (1977) Polyadenylate in the virion RNA of mouse hepatitis virus. J Biochem (Tokyo) 82:1103-1108

Yoshikura H, Taguchi F (1978) Mouse hepatitis virus strain MHV-S. Formation of pseudotypes with a murine leukemia virus envelope. Intervirology 10:132-136

Yoshikura H, Tejina S (1981) Role of protease in mouse hepatitis virus-induced cell fusion. Virology 113:503-511

Van der Zeijst BAM, Horzinek MC, Jacobs L, Rottier PJM, Spaan WJM (1981) Messenger RNAs of mouse hepatitis virus A59: isolation and characterization, translation in Xenopus laevis oocytes of RNAs 3, 6, and 7, UV target sizes of the transcription templates. In: ter Meulen V, Siddell S, Wege H (eds) Biochemistry and Biology of Coronaviruses. Plenum Press, New York, pp 209-226 